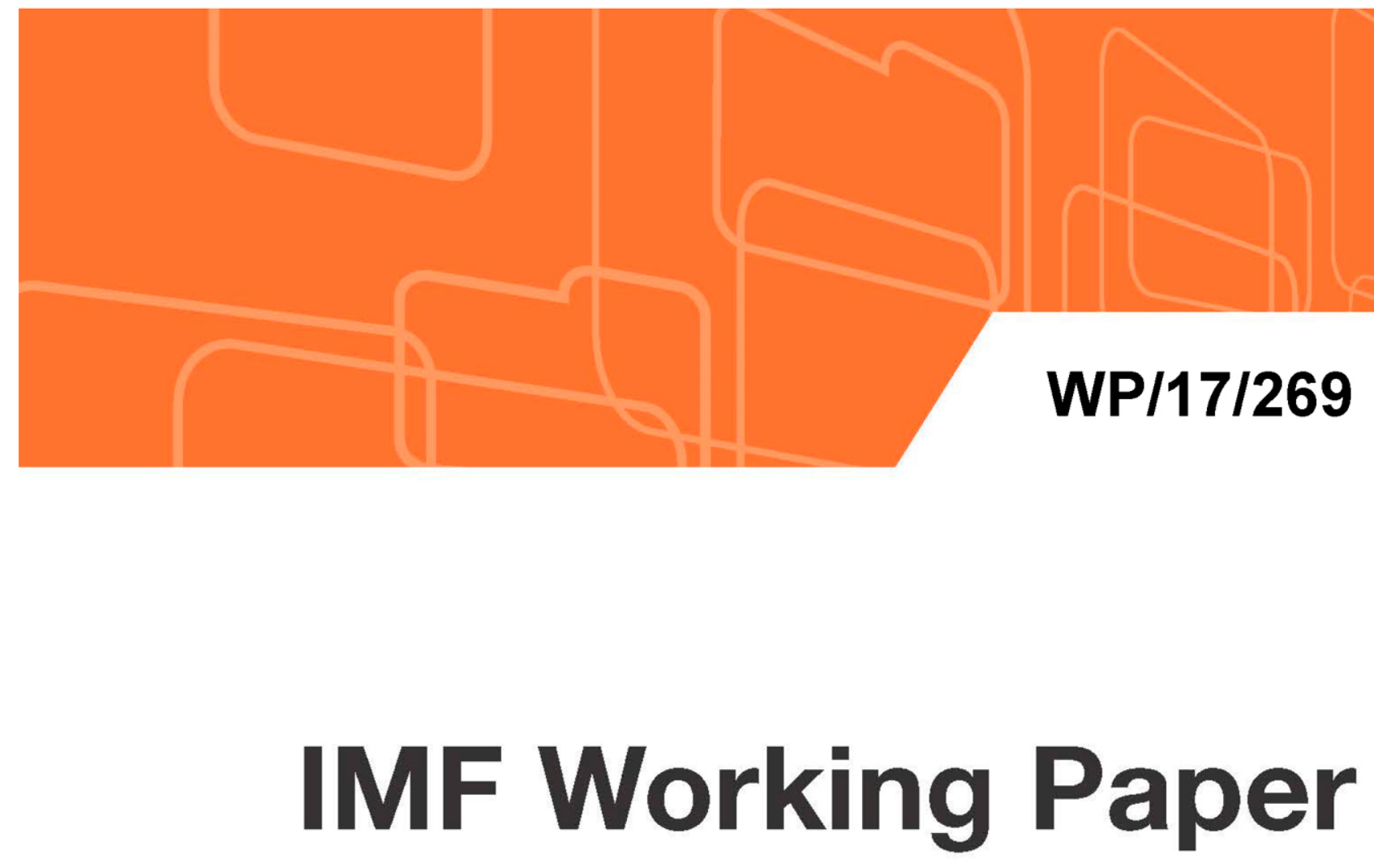

\title{
Incorporating Macro-Financial Linkages into Forecasts Using Financial Conditions Indices: The Case of France
}

by Piyabha Kongsamut, Christian Mumssen, Anne-Charlotte Paret, Thierry Tressel

IMF Working Papers describe research in progress by the author(s) and are published to elicit comments and to encourage debate. The views expressed in IMF Working Papers are those of the author(s) and do not necessarily represent the views of the IMF, its Executive Board, or IMF management.

$$
\text { I N T E R N A T I O N A L M O N E T A R Y F U N D }
$$




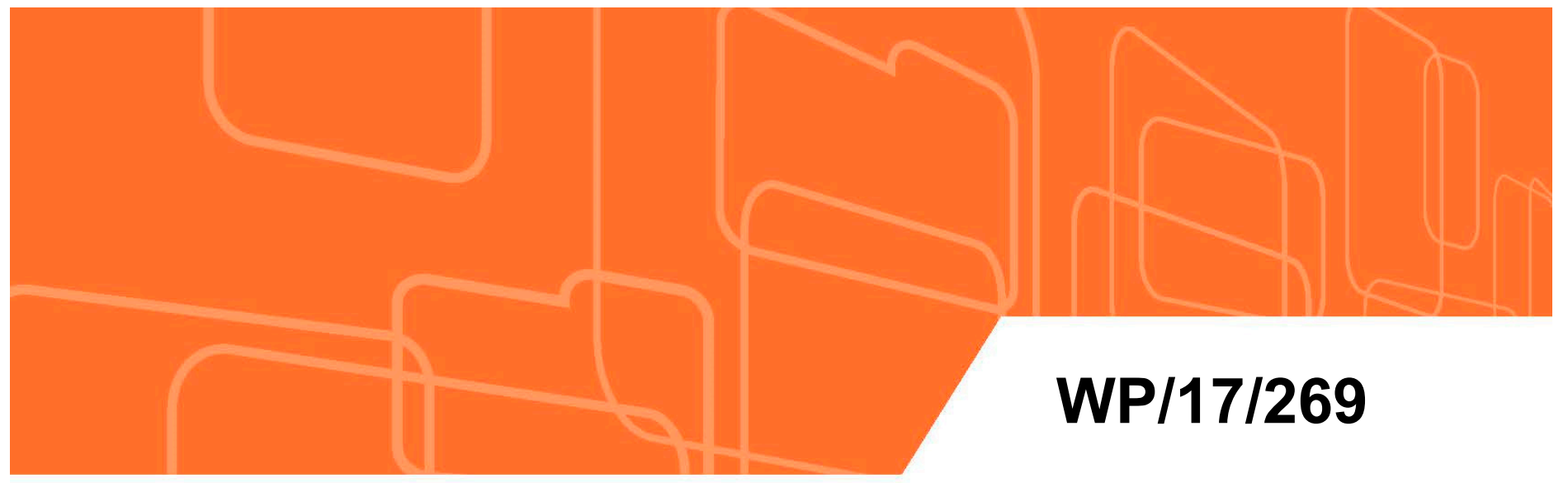

\section{IMF Working Paper}

\section{Incorporating Macro-Financial Linkages into Forecasts Using Financial Conditions Indices: The Case of France}

by Piyabha Kongsamut, Christian Mumssen, Anne-Charlotte Paret, Thierry Tressel

IMF Working Papers describe research in progress by the author(s) and are published to elicit comments and to encourage debate. The views expressed in IMF Working Papers are those of the author(s) and do not necessarily represent the views of the IMF, its Executive Board, or IMF management.

$$
\text { I N TER N A T | O N A L M O N E T A R Y F U N D }
$$




\title{
IMF Working Paper
}

European Department

\section{Incorporating Macro-Financial Linkages into Forecasts Using Financial Conditions Indices: The Case of France ${ }^{1}$}

\section{Prepared by Piyabha Kongsamut, Christian Mumssen, Anne-Charlotte Paret, Thierry Tressel ${ }^{2}$}

Authorized for distribution by Christian Mumssen

December 2017

\section{IMF Working Papers describe research in progress by the author(s) and are published to elicit comments and to encourage debate. The views expressed in IMF Working Papers are those of the author(s) and do not necessarily represent the views of the IMF, its Executive Board, or IMF management.}

\begin{abstract}
How can information on financial conditions be used to better understand macroeconomic developments and improve macroeconomic projections? We investigate this question for France by constructing country-specific financial conditions indices (FCIs) that are tailored to movements in GDP, investment, private consumption and exports respectively. We rely on a VAR approach to estimate the weights of the financial components of each FCI, including equity market returns (which turn out having a relatively strong weight across all FCIs), private sector risk premiums, long-term interest rates, and banks' credit standards. We find that the tailored FCIs are useful as leading indicators of GDP, investment, and exports, and as a contemporaneous indicator of private consumption. Credit volumes turn out to be lagging indicators of growth. The indices inform us on macro-financial linkages in France and are used to improve the accuracy of quarterly forecasting models and high-frequency "nowcast" models. We show that FCI-augmented models could have significantly improved forecasts during and after the global financial crisis.
\end{abstract}

JEL Classification Numbers: E27, C3, E3, E1

Keywords: France, financial conditions index, macro-financial linkages, vector auto-regression, forecasting.

Author's E-Mail Address: pkongsamut@imf.org; cmumssen@imf.org; aparet-onorato@imf.org; ttressel@imf.org

\footnotetext{
${ }^{1}$ The authors are grateful to Laurent Clerc, Srobona Mitra, Sophia Chen, counterparts at the Institut National de la Statistique et des Etudes Economiques, at the Banque de France and seminar participants at the French Treasury and at the IMF for useful comments.

${ }^{2}$ International Monetary Fund.
} 
TABLE OF CONTENTS

$\begin{array}{ll}\text { CONTENTS } & \text { Page }\end{array}$

AbSTRACT — $\underline{2}$

TABLE OF CONTENTS __ $\underline{\underline{3}}$

I. INTRODUCTION — $\underline{\underline{5}}$

II. HOW WE DEPART FROM THE LITERATURE AND WHY __ $\underline{7}$

III. FIRST STEP: CONSTRUCTING THE FCIS ___

A. Selection of Financial Variables

B. VAR-based FCIs _

C. Weights of the Financial Variables in the FCIs ___

D. Granger-Causality Tests

E. Illustration: Evolution of FCIs and Macroeconomic Variables ___

IV. SECOND STEP: ASSESSING MACRO-FINANCIAL LINKAgES AND THE ForECASTING CONTRIBUTION OF THE FCIS

A. Forecasting Economic Variables with the Quarterly FCI __

B. In-sample Quarterly Forecast Performance _

C. Out-of-sample Quarterly Forecast Illustration __ 22

D. Monitoring Activity During the Quarter ___ 24

V. CONCLUSION__

REFERENCES __ $\underline{27}$

APPENDIX__ $\underline{30}$

A. Data Description $\quad \underline{30}$

B. Construction of the FCIs Linked to Components of GDP _ _

C. Granger Causality Tests __

D. Nowcast Models __ $\underline{33}$

\section{FIGURES}

1. Responses of GDP Growth to Financial Variables $\underline{13}$

2. Granger Causality Tests 17

3. Financial Conditions Indices and the Real Economy

4. One Quarter-ahead Forecast Error

\section{TABLES}

1. Effect of Financial Shocks on GDP Growth Derived from Impulse Responses

2. Weights of the Financial Variables in the GDP-linked FCI $\underline{14}$

3. Weights of the Financial Variables in the Consumption-linked FCI $\underline{15}$

4. Weights of the Financial Variables in the Investment-linked FCI

5. Weights of the Financial Variables in the Exports-linked FCI 16 $\underline{16}$

$\underline{16}$


6. GDP Forecast Models: Root Mean Square Errors Relative to the Benchmark Model without FCI

7. GDP Components' Forecast Models: Root Mean Square Errors Relative to the Benchmark Model without FCI $\underline{21}$

8. Nowcast models: RMSEs Relative to Benchmark Model without FCI

$\underline{24}$

APPENDIX TABLES

A1. Quarterly Variables $\underline{30}$

A2. Monthly Variables $\underline{30}$

A3. Financial Variables Integrated in the FCIs $\underline{31}$

A4. Causality from the Specific FCIs to the Targeted Variables $\underline{32}$

A5. Causality from the GDP-linked FCI to Credit Flows $\underline{32}$

A6. GDP Nowcast Model $\underline{33}$

A7. Consumption Nowcast Model $\underline{34}$

A8. Investment Nowcast Model $\underline{35}$

A9. Exports Nowcast Model $\underline{36}$ 


\section{INTRODUCTION}

This paper investigates the transmission of financial conditions to real economic activity in France, with the objective of enhancing the accuracy of macroeconomic forecasts. The global financial crisis of 2008-09 and the subsequent crisis in the euro area highlighted the impact that conditions in financial markets can have on macroeconomic developments in advanced economies. However, these macro-financial linkages can differ significantly across countries and may change over time, and financial conditions can affect the real economy through different channels. France enjoys a comparatively stable rate of private consumption growth and credit growth, and access to credit is generally good. While macro-financial linkages have been well studied in the US or the UK where capital markets dominate the financial system, there is relatively less understanding of how financial conditions are transmitted to real economic activity in France where the financial sector is bank-based and savings are typically invested in debt instruments, which often offer regulated returns. It is thus not obvious a priori how financial conditions are transmitted to the real economy in France, whether financial conditions in France would be leading or lagging indicators of real economic activity, and would help improve the accuracy of macroeconomic forecasts.

We seek to identify financial conditions that are leading indicators of real economic activity. The interaction between financial conditions and the real economy is complex. Financial conditions can have a direct impact on the real economy, and conversely the real economy tends to affect financial conditions. Moreover, financial variables contain information about how markets perceive current and future real developments. The aim of this paper is to identify financial variables that are informative leading indicators for real GDP growth and its components, and can thus help improve macroeconomic forecasts, be it due to a causal or a purely statistical effect. We do not analyze the reverse links, i.e., financial indicators that tend to lag real developments. We also do not analyze whether these indicators can be early warning indicators of financial market risks and volatility.

We consider interest rates, risk premiums, indicators of credit standards, and asset prices as potential leading indicators. Several financial variables are likely to be needed to characterize its multidimensional interactions with the real economic activity. Financial conditions can impact real economic activity through borrowing conditions or asset prices, and these borrowing conditions can vary across sectors (households and non-financial corporations). Borrowing conditions depend not only on interest rates but also on non-price lending standards which can either restrict or facilitate borrowers' access to bank credit. The demand of credit for investment purposes can be affected as a result, but consumption can also be impacted through the intertemporal cost of acquiring real estate, the value of real estate assets, or the cost of consumer credit. Financial market prices such as equity valuations and long-term interest rates impact the return on savings (causing wealth and substitution effects), and also contain information on the perception of current and future economic performance and risks, and on the tolerance to the latter.

We construct four financial conditions indices tailored to help explain movements in real GDP, investment, private consumption and exports. We follow a parsimonious approach and focus on the methodology and indicators that best fit our objective of improving forecasts for GDP and its components. The weights of these financial variables in 
each specific FCI are based on a two-step VAR model approach. They are directly linked to the impact they have on the growth rate of the targeted macro variable; and they incorporate information on the sign, the magnitude and the timing of this impact. The value added of our FCIs relative to equally weighted FCIs (which would assume that each financial variable matters equally) is founded on the two-step approach. This approach allows to identify the financial aspects that have the best forward looking properties vis-à-vis our real variables, amongst the different financial conditions being at play. The indices are then used to improve the accuracy of quarterly forecasting models and high-frequency "nowcasts". Our study covers the period 2003:Q1-2015:Q4, hence includes both pre-Global Financial Crisis and post-Global Financial Crisis years.

\section{This paper provides new insights on how financial conditions are channeled to economic activity in France, and how they can help anticipate real sector dynamics.} These innovations aim to construct a good financial conditions leading indicator of economic activity, based on the identification of macro financial linkages that are specific to France. Our key technical contribution is that we combine theory and what is observed in the data in a two-step vector autoregressive (VAR) approach to construct each FCI. There is to our knowledge no paper that has followed such a regression based approach to design FCIs in macro forecast models and use them to better understand macro-financial linkages in France. ${ }^{1}$ Moreover, this paper seems to be the first attempt to construct FCIs that are tailored to help explain movements, not only in GDP, but also in investment, consumption and exports, and showing that FCIs can help improve forecast and now-cast accuracy, in some cases to a significant extent. In fact, there is very limited literature making financial condition indices in macro-forecast models at a high frequency. First, we select the components of each FCI that can best predict each of the four macroeconomic aggregates (GDP, consumption, investment and exports) based on statistical criteria and sign restrictions that are consistent with economic theory. Once selected, we aggregate the variables into FCIs using weights derived from their historical co-movements and their cumulative impact on the targeted macroeconomic aggregates. Second, we construct quarterly forecast and high-frequency nowcast models that are augmented with the constructed FCIs. Macro econometric models that are used for policy and forecast purposes, in particular in the case of France, usually do not include financial variables. ${ }^{2}$

\section{The key findings of the paper are as follows:}

- We characterize key transmission channels of financial conditions to economic activity in France: financial conditions are captured by a combination of the equity market return, the long-term risk free rate, a sector-specific interest rate premium, and credit standards.

\footnotetext{
${ }^{1}$ Most FCIs for France are based on a factor analysis approach (see Paries, 2014). Refer for example to Pouvelle (2012) and Levieuge (2015) for credit growth forecasts based on financial variables for France.

2 The MESANGE model, used at the French Treasury to forecast GDP, does not incorporate financial conditions above the interest rate (see Allard-Prigent et al., 2002). Nor does the model developed by Barhoumi et al. (2008) for GDP short-term forecast for France. Combes et al. (2013) do show that the integration of financial variables allows to increase GDP nowcast performances, they however do not use an FCI in the proposed models.
} 
- $\quad$ Financial conditions are robust leading indicators, primarily via their effect on enterprise investment, and to a lesser extent on exports. By contrast, changes in financial conditions impact households' consumption contemporaneously, perhaps as a result of wealth effects, the impact of expectations, or common shocks on consumer and market sentiment.

- $\quad$ Our estimated weights show that equity market returns are the strongest leading indicator across all three macroeconomic components and GDP itself. This likely captures investor sentiment and market expectations of future economic activity, rather than reflecting a direct impact of greater ease of financing through the stock market. Thus, even though bank lending remains the predominant form of financing in France, equity market movements seem to provide the strongest signal about shortterm economic prospects. Credit spreads are also strong leading indicators, particularly for investment and net exports, while credit standards also provide leading information on short-term economic prospects.

- $\quad$ FCI-augmented VARs help enhance standard quarterly VAR-based macroeconomic forecasts. Each FCI can help improve predictions of future real GDP, consumption, investment and real exports one to three quarters ahead. Depending on which macroeconomic component is considered, these VARs take into account macroeconomic and price dynamics, as well as oil prices, world growth, the real effective exchange rate or the change in unemployed labor force.

- The FCIs also help improve monthly "now-cast" models particularly during the first month of the quarter. Such monthly models could ultimately be used for scenario analysis, by applying shocks to the FCIs and assessing their impact on real activity through specific channels (consumption, investment or exports).

The paper is organized as follows: Section II reviews the existing literature that constructs financial conditions indices and uses them to forecast real economy dynamics. Section III presents our methodology and describes the evolution of the financial conditions indices we develop using this methodology. Section IV presents the short-term forecast and now-cast models and shows how their performance is enhanced by the integration of the FCIs in each respective model. Section V concludes.

\section{HOW WE DEPART FROM THE LITERATURE AND WHY}

Our work is related to three strands of the literature. The first one deals with different construction methods of FCIs, differentiating non-parametric statistical methodologies such as principal component analysis approaches, from regression-based methodologies (where the weight of each financial indicator is constructed based on its contribution to the growth rate of a real target variable). The second strand of the literature focuses on the evidence of macro-financial linkages and the use of FCIs in macro forecast models. Last, we also build on the literature developing high-frequency now-cast models.

A lesson from the literature is that data-driven methodologies can incorporate a large amount of information, but can be difficult to interpret from an economic point of view. 
The construction of FCIs requires choosing the number and types of the variables to be included, and the method used to aggregate these variables in an index. The easiest way is to equally weight the financial variables (IMF FSI, $I M F, 2008, I M F, 2017$, Bloomberg FCI, Rosenberg, 2008, ECB FCI, Altavilla, Darracq-Paries, Nicoletti, 2015). This method is the most straightforward to implement, but remains relatively arbitrary. In contrast, widely used statistical data-driven methods (factor models) consist of summarizing the information contained in a great number of financial variables into a few unobserved common factors. The FCI is then usually constructed as the sum of the first factors that capture a high enough share of the co-movements between these financial variables. In such frameworks, the weights of the variables in the FCI correspond to their loadings on the first common factors, in static Principal Component Analyses (PCA hereafter) - see for instance Saint Louis Fed FSI, Kliesen and Smith (2010), Deutsche Bank FCI, Hooper, Mayer and Slok (2007), Morgan Stanley FCI, Morgan Stanley (2015) and ECB FCI, Angelopoulou, Balfoussia, Gibson (2013) and Darracq-Paries, Maurin, Moccero (2014) — or dynamic factor models - Gilbert and Mayer (2005), Brave and Butters (2012), IMF FCI, Matheson (2012), Hatzius et al. (2010) and IMF (2017). These data-reduction processes allow to integrate information from a large number of variables and are able to provide a simple but exhaustive characterization of financial conditions. However, an important drawback of this approach is that the stance of financial conditions cannot be easily interpreted, nor linked to identified aspects of financial conditions. Since we would like to use the results for forecasting and scenario analysis, we decided against using the more data-intensive approaches, as they would have required making assumptions on the evolution of many variables, without clear gains.

We follow the so-called "regression-based" approach constructing FCIs by directly taking into account the information on the link between each of the financial variables and a macroeconomic variable (GDP growth or industrial production for example). Specifically, the weight of each financial variable in the FCI corresponds to its contribution to the growth of the macro variable. Measuring this contribution can be done with a reduced form equation (such as in the OECD FCIs constructed by Guichard and Turner, 2008; the Goldman Sachs FCI, Goldman Sachs, 2015 and the Citi FCI, D'Antonio, 2008) or impulse responses based on a VAR estimation (Goodhart and Hofmann, 2001, Gauthier et al., 2004). In a VAR-based approach, the weight of each of the financial variables entering the FCI would be equal to the average impact of a 1-unit shock to this variable on the macro variable over the following quarters, based on the cumulative impulse response functions (IRFs). Studies using this method usually have recourse to a Cholesky decomposition, ordering the variables in the VAR according to their relative sluggishness (which can be associated with the degree to which they respond to developments in other variables within the quarter, see Goodhart and Hofmann, 2001 and IMF, 2008). ${ }^{3}$

Studies generally select a few financial variables in their FCIs. The number of variables to be integrated in the FCI depends on the aggregation methodology. In fact, equally weighted FCIs and VAR regression based approaches generally build only on a few variables (for example, seven for the IMF Financial Stress Index, IMF, 2008). IMF (2017) considers 10 financial indicators. In terms of the type of variables, FCIs commonly integrate interest

\footnotetext{
${ }^{3}$ Gauthier (2004) relies on generalized IRFs, so as to avoid dependence of the IRFs on the financial variables ordering in the VAR.
} 
rates and spreads (as proxies of specific risk premiums), equity market returns and exchange rates. Recent studies also take into account credit standards (see for example Guichard and Turner, 2008, for the United States). In contrast PCA-based FCIs rely on a great number of complementary variables (18 in Kliesen, Owyang, and Vermann, 2012; 100 in Brave and Butters, 2012, 62 in Darracq-Paries, Maurin, Moccero, 2014, 45 grouped into five categories for Hatzius et al., 2010). Moreover, due to data availability and to the fact that they take into account more information than indices focused on financial stress (notably lending surveys, consumer related and quantity variables), FCIs tend to show better performance in forecasting macroeconomic variables (Kliesen et al., 2012). In this paper, we use only a few variables to construct a simple, easily interpretable FCI, which allows to identify how a financial tightening or loosening is transmitted to the real economy.

Regression-based FCIs can be corrected for the business cycle and price dynamics. Hatzius et al. (2010) argue that, independently from the choice of the variables and the way they are aggregated together, financial variables have to be corrected for the business cycle and price dynamics if one wants to identify the impact of exogenous financial shocks on macroeconomic activity. The underlying idea is to assess the marginal predictive value of the resulting FCI, when it is purged from its endogenous macroeconomic component. However, Hatzius et al. also show that "purged" FCIs do not necessarily lead to higher forecast performance. In fact, the purged version of their PCA-based FCI performs better than the non-purged one in forecasting growth for some sub-periods (in the early 90 s and in the 2000s) and worse for others (80s and in the late 90s). In the same vein, Darracq et al. (2014) exploit sign restrictions to identify credit shocks in the FCI and their impact on economic activity in the four large euro area countries (Germany, France, Italy and Spain). In this paper, we follow a standard VAR-based approach without applying any correction to the financial variables included in the FCIs. ${ }^{4}$

Once FCIs are constructed, including them into economic activity forecast models can significantly improve in-sample performance on a quarterly frequency. Provided they are correlated with future activity, the fact that financial variables are released earlier and more frequently than GDP figures makes them good candidates to enhance macroeconomic forecast models (see Gerdrup et al., 2006, which notably emphasize the correlation between selected financial variables and several quarters-ahead GDP growth). The most straightforward method is to use a reduced form model where the dependent variable is the targeted macro-variable and which includes an FCI as a regressor (see English and Tsatsaronis, 2005, Wacker and Lodge, 2014). Matheson (2012) and Kliesen et al. (2012) use a VAR to forecast GDP or industrial production growth, the FCI being included in the model as an endogenous variable, together with other variables (such as inflation and a real short-term interest rate in Matheson, 2012). Such specifications take into account the feedback between the endogenous variables entering the VAR. They also present the advantage not to rely on structural assumptions nor on any assumption of exogeneity of the variables (as in the reduced form models). As suggested by Krainz (2011), they are "a neutral way of observing interdependencies between variables" and "a theory-free way to capture dynamics in multiple time series". It would also be possible to run forecast models allowing for nonlinearities in

\footnotetext{
${ }^{4}$ An alternative would have been to estimate a Vector Error Correction Model, but VARs are simpler and better adapted to short-term forecasts.
} 
the macro financial linkages. However, Levieuge (2015) shows that a threshold VAR to model regime switching does not significantly improve the accuracy of forecasts of credit growth in France compared to a simple VAR augmented with equity prices, because it fails to accurately predict the right regime (which is determined by equity prices).

\section{Various papers develop shorter-term empirical models to forecast current macroeconomic variables using higher frequency information on economic activity.} These "nowcast" models commonly aim to monitor activity during a specific quarter and to forecast GDP growth that will only be released sometime after the end of the quarter (45 days in the case of France). They typically include qualitative indicators (surveys of consumer or business confidence) and quantitative data (providing information on past real activity and therefore available after qualitative surveys, such as industrial production or retail sales). These models are typically based either on a small number of well selected variables, or rely upon statistical tools to aggregate the co-movements between a high number of financial variables into a few common factors. In the former models, the selected variables are typically chosen thanks to automatic selection procedures (see Sédillot and Pain, 2005, Bec and Mogliani, 2015, which notably consider BIC-based model selections). To deal with mixed frequency data, the blocking approach methodology used for nowcast models consists in breaking the monthly series down into three different quarterly series (corresponding to the first, second and third months of each quarter), so as to be able to integrate high frequency information in the quarterly estimations of GDP growth (see Bec and Mogliani, 2015, for details). Depending on the point in time where the nowcast is made, the model can include one, two or three of these series. For each variable to be forecasted, different models can then be estimated depending on the information available at each point in time. The most complete tool (such as the one developed at the French Treasury, described in Lalande and Rioust de Largentaye, 2015) would correspond to one different model to use each time a new indicator is published, so as to make use of the most recent information in an exhaustive way, and get the best possible nowcast at each point of time. An intermediate possibility (see Bec and Mogliani, 2015) is to run three different models corresponding to the nowcasts that can be run when one month, two months or three months of data are available. This is the option we choose, balancing simplicity of the model and nowcast accuracy in nowcast models where we integrate the early available financial information aggregated in our monthly FCIs.

\section{First Step: Constructing The FCIS}

This section describes the construction of the FCIs. It first explains how we select the set of financial variables that we consider as potential candidates for the FCI, based on standard economic theory and statistical criteria. Second, it presents the VAR-based methodology used to construct the FCIs using the financial variables selected. The construction is illustrated with details on the GDP FCI, but the methodology used to construct the consumption, investment and export specific FCIs is the same. The details related to the construction of each specific FCI can be found in Appendix B. Third, the weights of the financial variables in the tailored FCIs are discussed. Fourth, Granger-causality tests are conducted to test the leading properties of the constructed FCIs. Finally, we illustrate our findings with a description of the evolution of our FCIs from 2003 to 2016. 


\section{A. Selection of Financial Variables}

The financial variables are selected from six broad categories covering the period 2003:Q1-2015:Q4. For each FCI, we include at most one variable selected from up to six pre-determined broad categories covering both price and non-price indicators, and both banks and financial markets: (i) interest rates, (ii) spreads or "risk premium", (iii) equity market returns, (iv) credit standards, (v) credit quantities, and (vi) exchange rate. These are consistent with the literature, which tends to consider that interest rates (and spreads), price variables (among which asset prices and exchange rates) and quantity or credit-related variables allow to cover the major channels of transmission of financial conditions to the real economy. Limiting the components of the FCI helps avoid redundancies and allows a clear identification of transmission channels.

To be included in the FCI, the coefficient of each variable has to be consistent with economic intuition and enhance forecast performance of the final FCI for GDP and each of its components. For each category, the macroeconomic impact of the variable chosen must be correctly signed (to ease economic interpretation of the resulting FCI) and must increase the forecast performance of the FCI compared to models including other candidate variables. We test various VAR specifications, always including the inflation rate as a control variable.

Based on this selection approach, our FCIs include a risk-free rate, a sector specific spread, sector specific lending standards, and equity market returns. The long-term risk free rate was preferred to a short-term risk free rate because the coefficient of the latter was found to be less robust to specification changes. To avoid redundancy, we keep only one private sector spread or risk premium in each FCI. ${ }^{5}$ We find evidence that enterprises' and mortgage credit standards, 10-year Treasury bond rates, NFCs' and mortgage risk premiums and equity market returns have forward looking properties that could help to anticipate movements in economic variables, once they are aggregated into a FCI (see details for each specific FCI in Appendix B).

The financial variables integrated in each FCI are specific to the macroeconomic variable to be forecasted. For example, the risk premium considered for the investment and for the exports' FCIs is the spread on loans to non-financial corporations (to the 10 -year Treasury bond interest rate), whereas it is the spread on mortgage loans for the consumption FCI. Similarly, we considered enterprises' credit standards for the investment and exports FCIs, whereas we integrated the mortgage credit standards in the consumption FCI.

\footnotetext{
${ }^{5}$ Another measure of spread not considered, such as the Libor-OIS spreads, captures credit risks in the banking system, and while relatively flat in normal times, tends to spike during episodes of financial crisis (2008 and 2011-12). Being correlated with stock market returns, it has not been considered.
} 
After extensive testing, we concluded that neither credit quantities nor exchange rates should be included in the FCIs:

- Credit flows are lagging indicators of financial conditions of real economy dynamics (and are often incorrectly signed). Running Granger-causality tests, we also find that the final GDP FCI (without quantity variables) contains information to predict credit growth (in particular 2 and 3 quarters ahead, as illustrated in Appendix C).

- Exchange rates were not correctly signed and led to lower forecast performance of the resulting FCIs. ${ }^{6}$

\section{B. VAR-based FCIs}

The weight of each financial variable in the FCI is defined as its average impact over eight quarters on the targeted variable's growth in a VAR framework. Formally, we estimate the following VAR equation:

$$
X_{t}=\alpha+\sum_{i=1}^{p} \theta_{i} X_{t-i}+\varepsilon_{t}
$$

where $\mathrm{X}$ is a vector of jointly determined stationary variables: real growth of GDP, consumption, investment or exports, harmonized CPI inflation, and all the financial variables selected to be included in the FCI. Based on their relative sluggishness, we ranked real economy variables' growth and inflation as first and second, as both do not react instantaneously to changes in the financial variables. Credit standards come just after, because banks are unlikely to revise the stance of their lending standards too rapidly. We ranked risk free long-term interest rates right after, e.g. we assume that they evolve less rapidly than private sector risk premiums and stock market returns, including because government fundamentals tend to be more stable than those of the private sector. ${ }^{7}$ Both of these variables are ranked last, because they are expected to respond very quickly to changes in the other variables and to changes in the set of information available to financial market participants.

As an illustration, the VAR used to construct the GDP-linked FCI contains GDP growth, inflation, and the following set of financial variables: (i) the long-term risk free rate (10-year Treasury bond interest rate); (ii) the NFCs risk premium (spreads for NFCs

\footnotetext{
${ }^{6}$ However, the real effective exchange rate was included as an exogenous variable in our exports forecast model.

${ }^{7}$ This assumption may not always hold in general-as for instance during the euro area crisis when government bond yields in Germany or France responded quickly to changes related to the situation in Greece or in other countries, as a result of safe haven flow.

${ }^{8}$ We also experimented with the slope of the yield curve (e.g. a spread between the long-term risk free rate and a short-term interest rate), but found that the long-term risk free rate performed better in term of sign together with the other variables selected in the FCIs.
} 
loans over 2 years, to 10-year Treasury bond); (iii) the change in enterprises' and mortgage credit standards, ${ }^{9}$ and (iv) equity market returns (CAC40 total returns). ${ }^{10}$

Figure 1 pictures the impulse responses showing the impact of each of these financial variables on GDP growth, in this VAR framework. ${ }^{11}$ Table 1 illustrates the corresponding impact on GDP growth of standard shocks on the financial variables (cumulatively, over 8 quarters). The effects of the selected financial variables on GDP growth are of the same order of magnitude as those found by Guichard and Turner (2008) for US activity.

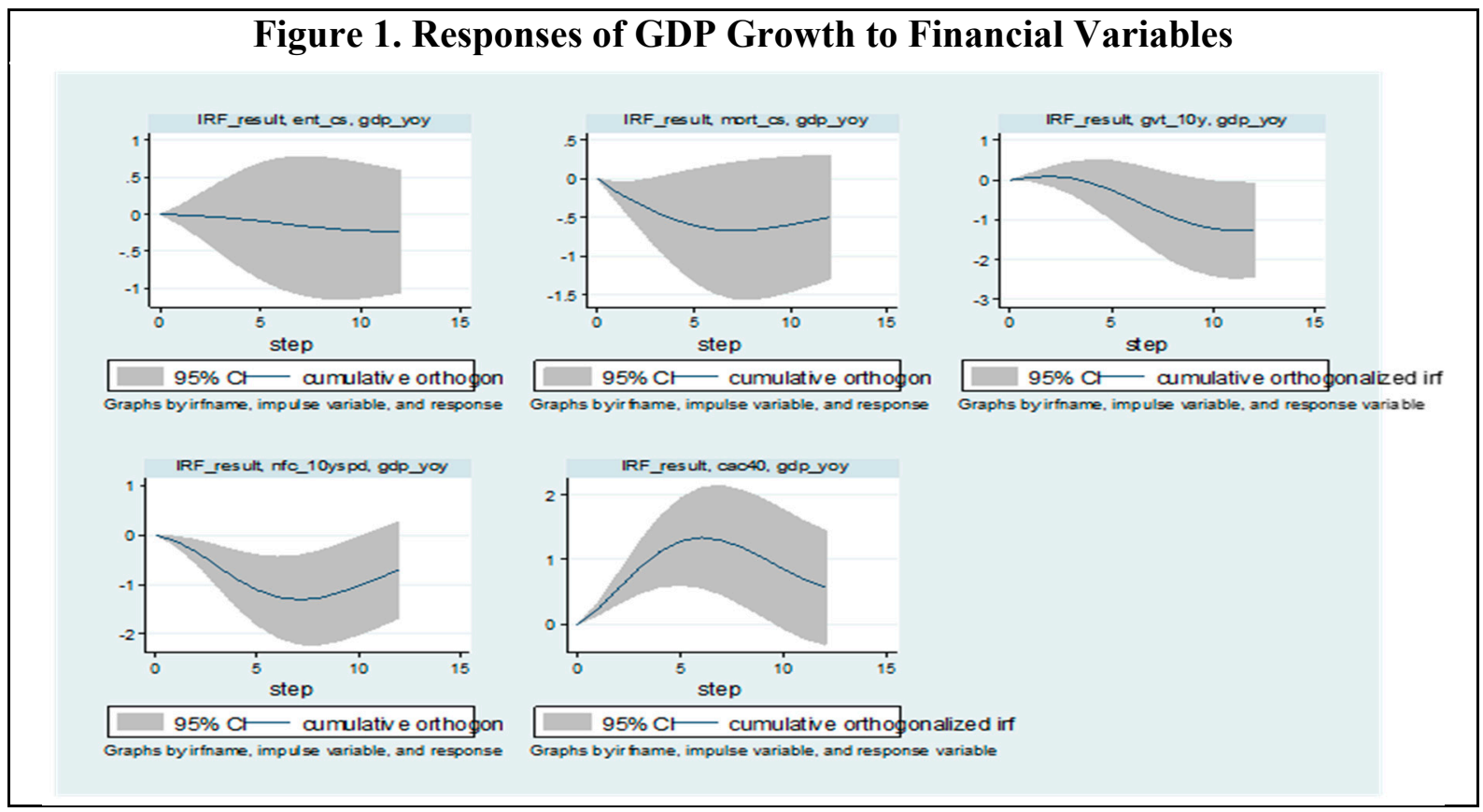

\footnotetext{
${ }^{9}$ Lending standards are from the Bank of France Bank lending survey. The questions asked in the survey are the following: "Over the past month, how have your bank's credit standards as applied to the approval of loans or credit lines to enterprises (resp. of loans to households for house purchase) changed?" Survey figures are reported as unweighted net percentage balances. There are 5 possible responses to each question, for example: tightened considerably, tightened somewhat, remained basically unchanged, eased somewhat or eased considerably. The net percentage balance is calculated as the difference between the sum of the percentage of responses for tightened considerably and tightened somewhat minus the sum of the percentage of responses for eased considerably and eased somewhat (=tightened considerably + tightened somewhat) - (eased somewhat + eased considerably)). Note that it includes bank credit standards for both enterprises and mortgages, incorporating contributors to financial conditions for all three macro sub-aggregates.

${ }^{10} \mathrm{We}$ also experimented with French and European volatility indices (e.g. vcac and vstoxx). However, for the sake of simplicity of the constructed FCIs, and because adding a volatility variable in the constructed FCIs did not lead to higher in-sample performance of the FCI augmented forecast models, they weren't retained in the main specifications. Appendix B presents the construction of the FCIs tailoring private consumption, investment and export growth using the same methodology as for GDP growth (see Appendix A for a description of the data).

${ }^{11}$ From the top-left to the bottom-right chart, the depicted IRFs respectively correspond to the impact on GDP growth of enterprises' credit standards, mortgage credit standards, long-term interest rate, NFCs' spread and equity market returns.
} 


\begin{tabular}{|lcc|}
\hline \multicolumn{2}{|c|}{ Table 1. Effect of Financial Shocks on GDP Growth Derived from Impulse Responses } \\
\hline Average cumulative effect, over 8 quarters & Shock & Effect on GDP (\%) \\
\hline Long-term risk free rate & 100 bps increase & -0.36 \\
NFCs spread & “ & -0.90 \\
Enterprises' credit standards tightening & 10 pp increase & -0.04 \\
Mortgage credit standards tightening & “ & -0.43 \\
Equity market returns & “ & 0.44 \\
\hline
\end{tabular}

\section{Weights of the Financial Variables in the FCIs}

Our estimations show that the FCIs can tighten due to an increase in the interest rate, a widening of the NFCs' spread, tightening lending standards or decreasing equity returns. The weights of the financial variables in the FCIs are computed as the average cumulative impact of a 1 standard deviation shock on the financial variables on GDP growth over the 8 quarters following the shock, as illustrated in Figure 1. They are displayed for each specific FCI, in Tables 4 to 7. In these tables, the weights are standardized, such that an increase in 1 unit of the FCI corresponds to the impact of a 1 standard deviation increase in the long-term risk free rate. With this normalization, an increase in the FCI corresponds to a tightening of financial conditions resulting from either one or several variables and is expected to have a negative impact on the real macroeconomic variable considered.

Equity market returns play the most economically significant role to anticipate GDP growth, followed by the spread on corporate loans. The large weight of the equity market could capture market sentiment effects or its role in financing non-financial corporations (though stock issuances usually play a more minor role as a source of external finance for investment). The stock market return may also aggregate market participants' expectations about future economic activity (such as firms' capacity to invest profitably and to generate cash flows, and the path of future risk free interest rates), and their views about risks, and therefore can have a predictive power with respect to macro-economic variables. Thus, even though bank financing is the predominant form of financing, it is the equity market that seems to provide the stronger leading financial indicator of short-term economic prospects. The prominent role of equity market returns is observable for each of the constructed FCIs, where it gets the largest weight. The NFC spread captures the cost of external finance for firms, including any risk premium which in turn are related to the outlook. Credit standards' tightening has a negative effect, which is statistically and economically significant for mortgages but not for lending to enterprises.

The components of GDP growth are not all affected by the same aspects of financial conditions, and not to the same extent, reflecting FCIs' different composition and weights.

- $\quad$ The consumption FCI tightens (with a negative impact on consumption growth) when equity market returns decrease, mortgage risk premium and long-term risk free rate increase, and, to a lesser extent, when mortgage credit standards tighten. A possible explanation is that the equity market return is likely to stimulate consumption via 
confidence effects. ${ }^{12}$ Alternatively, the equity market return incorporates information about future change of domestic demand, which highly depends on current private sector consumption growth, and this in turn would affect the outlook and firms' profits. The impact of the cost of mortgage repayments and mortgage credit availability can be interpreted as follows: 1) a lower cost of mortgage repayment increases the disposable income (after mortgage interest payments) of new buyers (who will buy anyway), and therefore increases their consumption while mortgage refinancing also boosts the disposable income of households who already have a mortgage, raising their consumption.; 2) when mortgage lending standards are loosened, the greater availability of mortgage credit also spurs more consumption (for example of durable goods) alongside the housing purchase.

- $\quad$ The investment FCI is driven mostly by equity market returns and to a lesser extent by the long-term risk free rate and the risk premium on loans to NFCs, which both tend to reduce investment growth when they increase. An interpretation is that this reflects, on the one hand, the effects of a favorable economic outlook on firms' perception of risk, and on the other hand, the impact of the cost of capital on investment decisions. Moreover, the negative but small impact of NFCs' credit standards' tightening on investment could be due to the fact that the bigger firms that are at the origin of major investment projects are less impacted by credit tightening than smaller firms, or possibly to the fact that significant volumes of fixed investment projects are financed by bond issuance rather than by bank loans.

- $\quad$ The export FCI is driven more equally by equity market returns, NFCs' credit standards and their risk premium. NFCs' credit standards do impact export growth significantly, showing that exports dynamics may be anticipated, not only with regard to perceptions of the well-being of the equity market, but also thanks to an assessment of the difficulty of the firms to find funding (both in terms of credit availability and funding cost).

\begin{tabular}{|lcc|}
\hline \multicolumn{3}{|c|}{ Table 2. Weights of the Financial Variables in the GDP-linked FCI } \\
\hline & Original weight $^{\mathbf{1}}$ & Weight in the FCI $^{\mathbf{2}}$ \\
\hline Long-term risk free rate & -0.28 & 1.00 \\
NFCs spread & -0.86 & 3.03 \\
Enterprises' credit standards tightening & -0.09 & 0.31 \\
Mortgage credit standards tightening & -0.50 & 1.77 \\
Equity market returns & 0.98 & -3.46 \\
${ }^{1}$ Average cumulative impact of a one standard deviation shock of the financial variable on GDP growth, over the \\
8 following quarters. \\
2 2 Standardized weight. \\
\hline
\end{tabular}

${ }^{12}$ Another channel could be through wealth effects, which have been found to be more important for example in the United States or the United Kingdom, but these have not been found to be strong in France. See Arrondel et al (2014) and Chauvin and Damette (2010). 


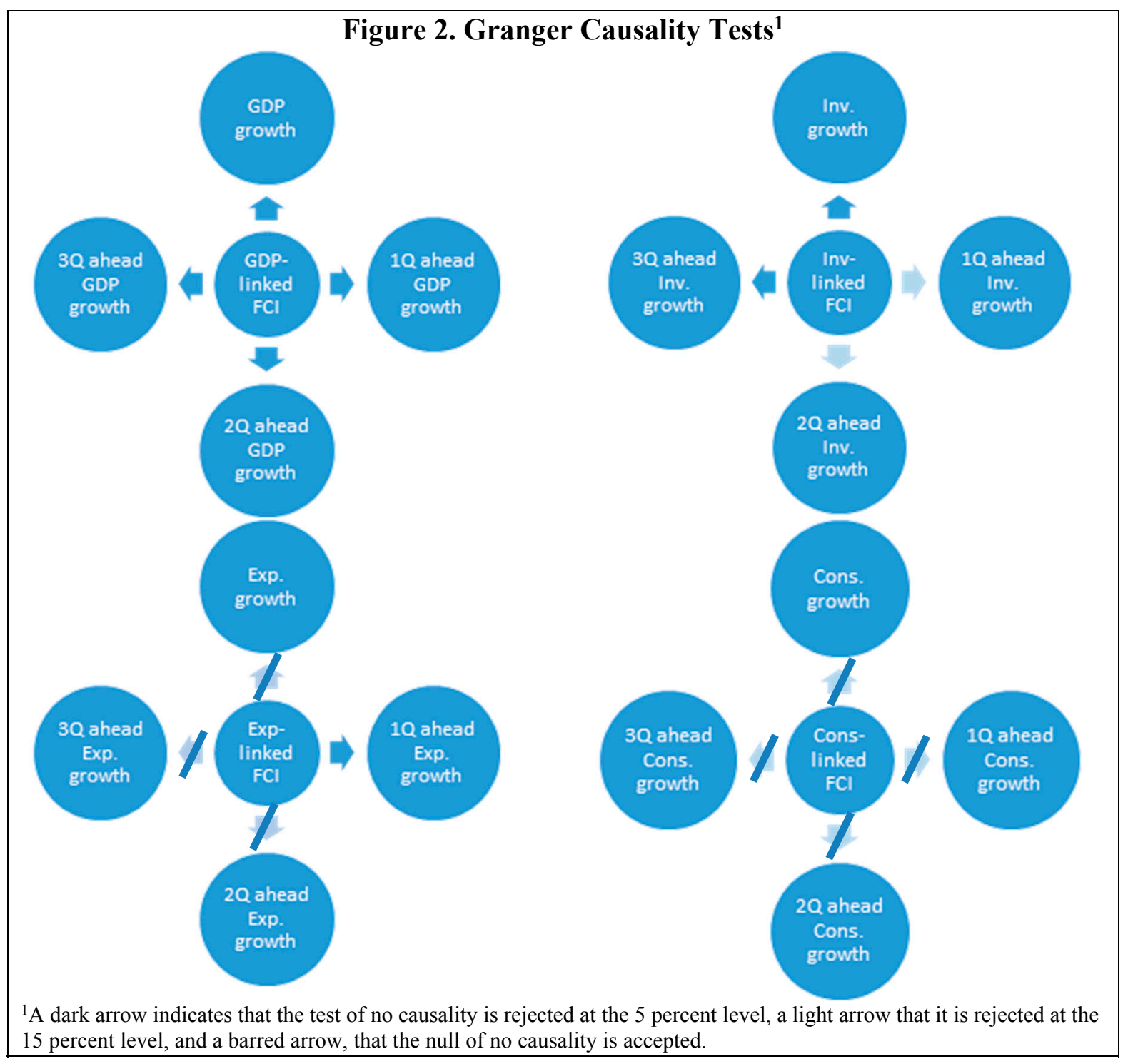

\section{E. Illustration: Evolution of FCIs and Macroeconomic Variables}

\section{All four FCIs clearly capture the tightening of financial conditions that occurred during the global financial crisis in 2008 and the euro area crisis in 2011, and illustrate the more recent evolution of FCIs (see Figure 3).}

- $\quad$ The 2008 global financial crisis. Financial conditions were very loose before the crisis, and were gradually tightening as a result of increasing long-term rates and widening private sector spreads. The tightening became abrupt from 2008:Q1 to 2008:Q4, due to a sharp fall in equity returns and a concurrent deterioration in credit standards. After the peak of the crisis, the loosening was supported by recovering equity markets and a notable decrease in risk premiums from 2009:Q1, to peak at the end of 2009. 
- The 2011 euro area crisis. Financial conditions tightened again before the euro crisis, with an intensification of the crisis from mid-2011, largely driven by declines in equity returns and increasing risk premia, and less so by tightening credit standard.

- $\quad$ More recently, monetary policy measures have kept conditions relatively loose until early 2016. After 2012, the ECB's announcement of further non-standard monetary measures and implementation of quantitative easing in 2014 seems to have been followed by a loosening of financial conditions, notably as observed in relaxed credit standards, low long-term risk free rates, increased equity returns and reduced corporate spreads (which can be easier seen on the investment and consumption graphs, as it weighs more in these specific FCIs). The moderate tightening in early 2016 is explained by the temporary downturn of the equity market.

\section{Summing up, our approach to constructing FCIs yields the following results:}

- $\quad$ Financial conditions as measured through our tailored FCIs are leading indicators for real GDP growth in France.

- Transmission from financial conditions to real activity appears to occur primarily through investment, and to a lesser extent via exports.

- $\quad$ Private consumption tends to move contemporaneously with its tailor-made FCI. Several interpretations are consistent with this finding:

(i) consumption and the FCI could be impacted by common (unobserved) shocks that simultaneously impact consumer confidence and market sentiment;

(ii) consumption could be directly and very quickly impacted by financial conditions through wealth effects. However, these effects would likely be small given the small share of stocks held as financial wealth in France;

(iii) a change in financial conditions (in particular stock prices, which contains information on future economic performance) could cause households to immediately revise their expectations of future income and wealth. ${ }^{14}$ A change in future expected income would have an immediate impact on consumption through intertemporal smoothing.

- Transmission occurs through the equity market, the risk free rate, a sector-specific risk premium, and credit standards.

- $\quad$ Equity market returns give the strongest effect across all three macroeconomic components and for GDP itself. Interest rates, spreads, and credit standards also impact macroeconomic variables significantly, although to varying degrees depending on the measure of real activity.

- Credit volumes appear to be a lagging indicator of real activity.

\footnotetext{
${ }^{14}$ See for a literature review of these channels the paper by Arrondel, Savignac and Tracol, 2014.
} 


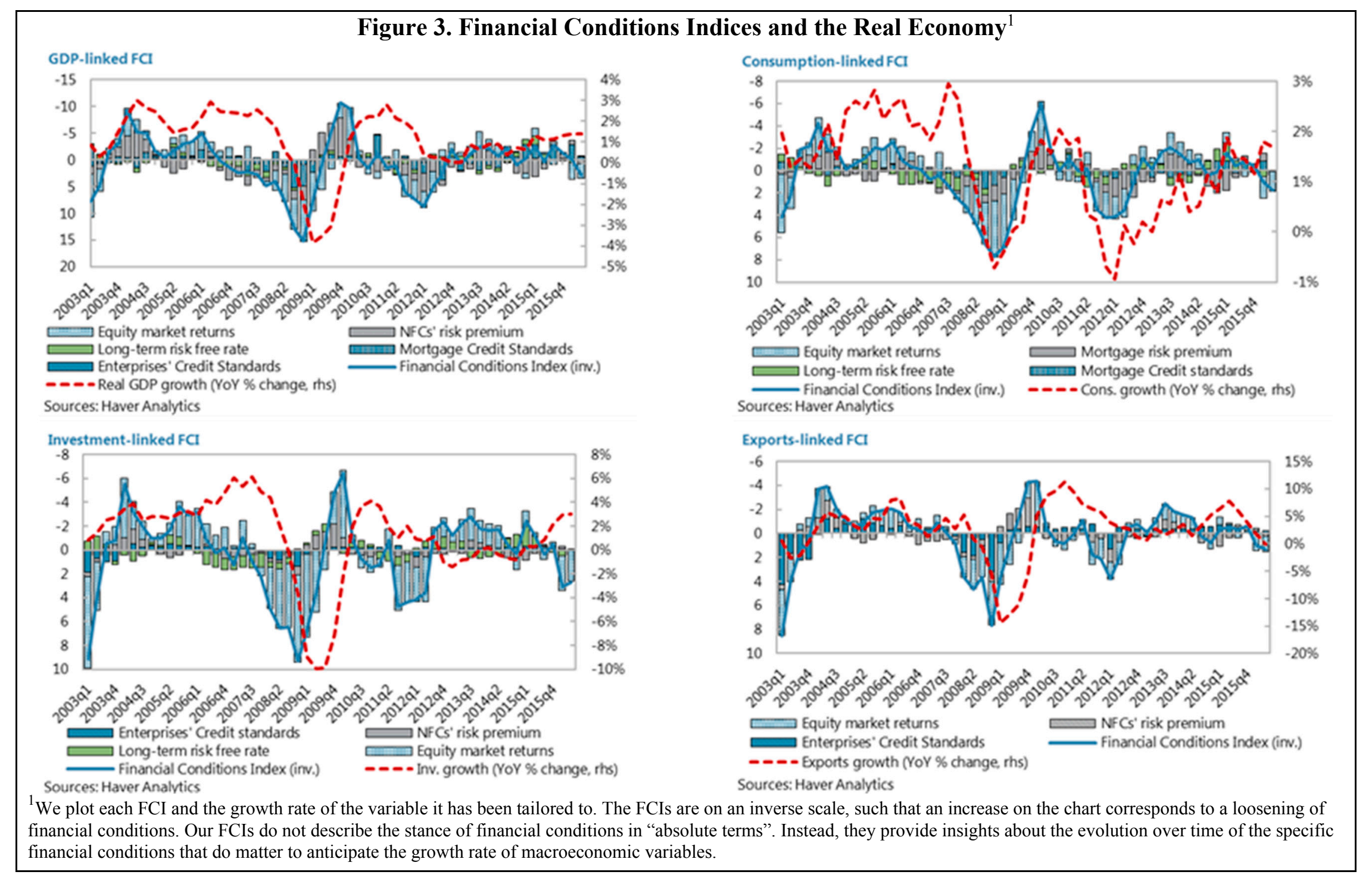




\section{SECond Step: Assessing MaCro-Financial Linkages and The Forecasting CONTRIBUTION OF THE FCIS}

We augment standard forecast and nowcast models with the constructed FCIs and assess whether the FCIs help deliver a better forecast of future real economy dynamics. We show that adding financial conditions improves in-sample forecast performance, and that the gain in performance is greatest for GDP compared to its components. We also find that FCIs can help improve nowcasting models, especially during the first month of a specific quarter.

\section{A. Forecasting Economic Variables with the Quarterly FCI}

Four models are estimated to forecast the growth rates of GDP, consumption, investment and exports. The specification with FCI is as follows:

$$
X_{t+h}=\sum_{i=1}^{p} \theta_{i} X_{t+1-i}+\rho Z_{t}+\varepsilon_{t}
$$

where $\mathrm{h}>1$. $\mathrm{X}$ includes the dependent variable, inflation and the FCI that is tailored to the dependent variable. $Z$ is the vector of exogenous variables (which is different for each of the dependent variables). For example, GDP growth is forecasted several quarters-ahead from current and lagged values of inflation and the FCI, and from current values of oil prices and world growth. ${ }^{17}$ The lag order of each VAR is chosen based on information criteria for current and 1-quarter ahead forecasts (with the same lag order selected for 2 and 3 quarters ahead forecasts $)^{18}$. We then proceed to in-sample forecasts of the target variable's growth for the current quarter, and at a 1 quarter, 2 quarter and 3 quarter horizon (see next section). The performance of the models with FCI are next compared with benchmark models that do not include financial conditions.

\section{B. In-sample Quarterly Forecast Performance}

All the FCI models improve the performance of the forecast compared to the benchmark model without FCI at all forecast horizons, particularly for GDP growth but also for each of its components. For each target variable, we assess the performance of our FCI augmented forecast model while comparing estimated GDP growth (resp. estimated components'growth) to its actual value, over the estimation sample. The in-sample forecast performance of the model augmented with the tailored FCI is compared to the performance of the benchmark model without FCI (Table 6 for GDP, Table 7 for the components), on the same estimation sample. A lower RMSE ratio (below one) indicates a more accurate forecast.

\footnotetext{
17 To forecast investment growth, we use current and lagged values of GDP growth, inflation and the FCI (endogenous variables), as well as current values of oil prices and world growth (exogenous variables). To forecast exports, we also integrate GDP growth, inflation and FCI as endogenous variables in the VAR, but real effective exchange rate and world growth as exogenous variables. To forecast consumption, we include GDP growth, inflation, FCI and changes in the number of unemployed as endogenous variables in the VAR.

${ }^{18}$ We allow for at most 4 lags to nowcast current GDP and for 2 lags to forecast several quarters ahead GDP, so as not to get forecasts of several steps ahead growth relying on data going too far back in time.
} 
Three robustness checks support the superiority of our FCI construction method in the case of France (Table 6 and Table 7). We first find that the purged versions of our FCIs do not perform significantly better than the standard ones. ${ }^{19}$ Second, the forecast models augmented with the IMF's Financial Stress Index (FSI) for France perform much worse than the forecast models augmented with our specific FCIs, whatever the horizon. Third, for the GDP model, we also compared the performance of our FCI macro model with a simple macro-model that includes a short-term interest rate. We find that our model with FCI performs better than the simple model with short-term interest rate, whatever the horizon considered. These findings suggest that constructing different FCIs that specifically tailor GDP, consumption, investment and exports is appropriate and that the regression-based approach performs well in extracting leading components from financial conditions.

\begin{tabular}{|l|cccc|c|}
\hline \multicolumn{5}{|c|}{$\begin{array}{c}\text { Table 6. GDP Forecast Models: Root Mean Square Errors Relative to the } \\
\text { Benchmark Model without FCI-Period 2003:Q1-2016:Q2 }\end{array}$} \\
\hline & current quarter & $\begin{array}{c}\text { 1Q- } \\
\text { ahead }\end{array}$ & $\begin{array}{c}\text { 2Q- } \\
\text { ahead }\end{array}$ & $\begin{array}{c}\text { 3Q- } \\
\text { ahead }\end{array}$ & Average \\
\hline GDP growth & & & & & \\
Standard FCI augmented model & 0.51 & 0.63 & 0.67 & 0.75 & 0.64 \\
Purged FCI augmented model & 0.60 & 0.70 & 0.72 & 0.70 & 0.68 \\
IMF FSI augmented model & 0.97 & 0.92 & 0.85 & 0.91 & 0.91 \\
Short-term rate augmented & 0.86 & 1.00 & 0.87 & 0.88 & 0.90 \\
model & & & & & \\
\hline
\end{tabular}

Table 7. GDP Components' Forecast Models: Root Mean Square Errors Relative to the Benchmark Model without FCI

\begin{tabular}{|l|cccc|c|}
\hline & current quarter & $\begin{array}{c}\text { 1Q- } \\
\text { ahead }\end{array}$ & $\begin{array}{c}\text { 2Q- } \\
\text { ahead }\end{array}$ & $\begin{array}{c}\text { 3Q- } \\
\text { ahead }\end{array}$ & Average \\
\hline Consumption growth & & & & & \\
Standard FCI augmented model & 0.95 & 0.81 & 0.78 & 0.75 & 0.82 \\
Purged FCI augmented model & 0.93 & 0.83 & 0.76 & 0.76 & 0.82 \\
IMF FSI augmented model & 1.01 & 0.98 & 0.98 & 0.98 & 0.99 \\
\hline Investment growth & & & & & \\
Standard FCI augmented model & 0.94 & 0.82 & 0.83 & 0.83 & 0.86 \\
Purged FCI augmented model & 0.83 & 0.79 & 0.88 & 0.92 & 0.86 \\
IMF FSI augmented model & 1.07 & 0.96 & 0.88 & 0.90 & 0.95 \\
\hline Exports growth & & & & & \\
Standard FCI augmented model & 0.88 & 0.71 & 0.81 & 0.83 & 0.81 \\
Purged FCI augmented model & 0.88 & 0.78 & 0.86 & 0.90 & 0.86 \\
IMF FSI augmented model & 0.99 & 0.94 & 0.93 & 0.91 & 0.94 \\
\hline
\end{tabular}

\footnotetext{
${ }^{19}$ The "purged" version involves correcting financial variables for the business cycle and price dynamics (see Hatzius et al, 2010).In this case, we corrected by manufacturing output and inflation using another VAR that includes the financial variable. The purged FCI is then constructed from the residuals of these VARs. The purged versions perform better only to some horizons for GDP, consumption and investment (3 quarter horizon for GDP, current quarter and 2 quarter horizon for consumption, current quarter and 1 quarter horizon for investment). The purged exports FCI always leads to a worse performance than the standard exports FCI to forecast exports' growth.
} 
Our analysis also suggests that FCI-augmented models could have enhanced GDP forecasts before and during the global financial crisis. Figure 4 shows the forecast errors of one quarter horizon forecasts for the models without and with FCI. We can observe that the FCI-augmented models explain real economy dynamics between 2006 and 2009 much better than the benchmark ones for GDP, investment and exports. Moreover, the FCI tailored for consumption enhances the forecast for consumption at the beginning of the Euro area crisis in 2011.

\section{Out-of-sample Quarterly Forecast Illustration}

An illustrative analysis suggests that the macroeconomic model with an FCI performs better than benchmark models over the most recent period from 2015:Q4 onward, for GDP, consumption and exports. The text chart presents evidence of out-of-sample performance of the GDP model augmented with the FCI, over the most recent period outside of our estimation period, and compares it with the benchmark model that does not include the FCI. Between 2015:Q4 and 2016:Q4, the average absolute difference between the actual quarterly real GDP and its forecast one quarter ahead is 0.5 percentage points with the benchmark model (green line) and 0.18 percentage point with the model augmented with the FCI (black line). As the estimation period timespan is short and quarterly financial data is used in the estimations, a more comprehensive out-ofsample analysis would require reducing the in-sample estimation, making the estimates less robust. In particular, incorporating crisis years in our in-sample estimation period is crucial to be able to anticipate similar events thanks to our FCI models. ${ }^{20}$

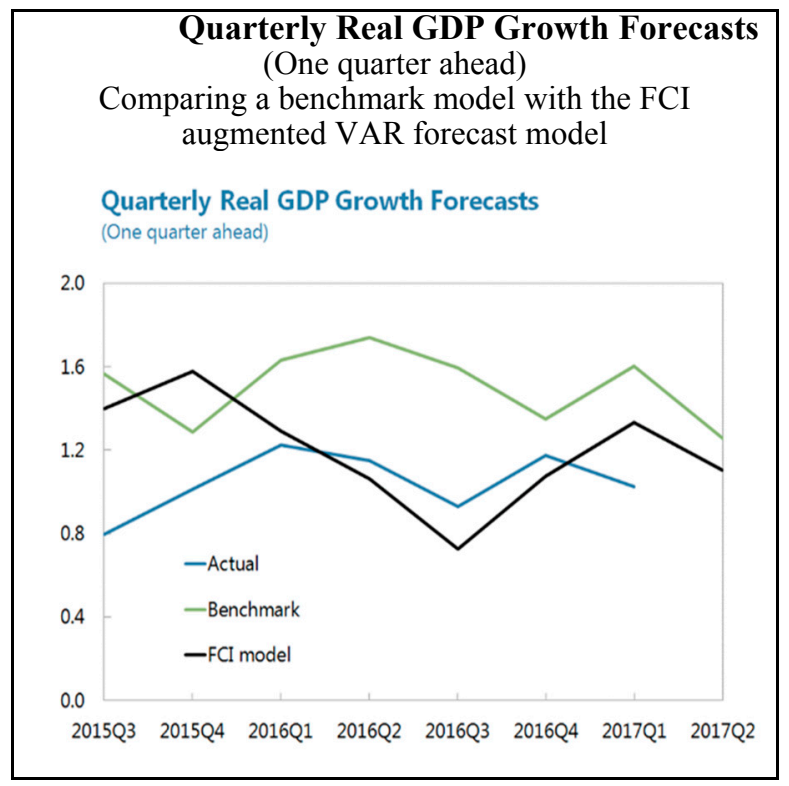

${ }^{20}$ IMF (2017) shows in a cross-country setting that macroeconomic models containing an FCI perform well in predicting downturns. 
GDP Forecast

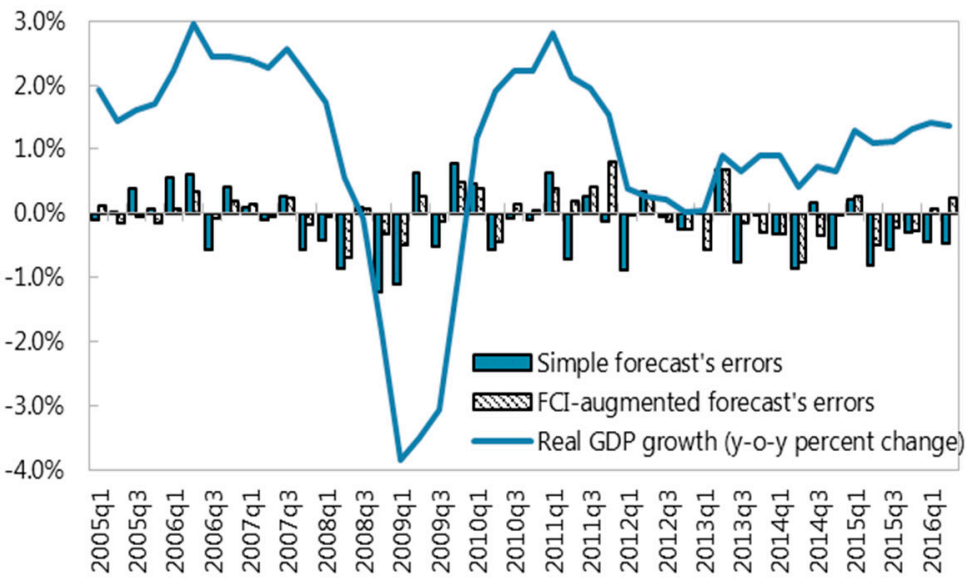

Investment Forecast

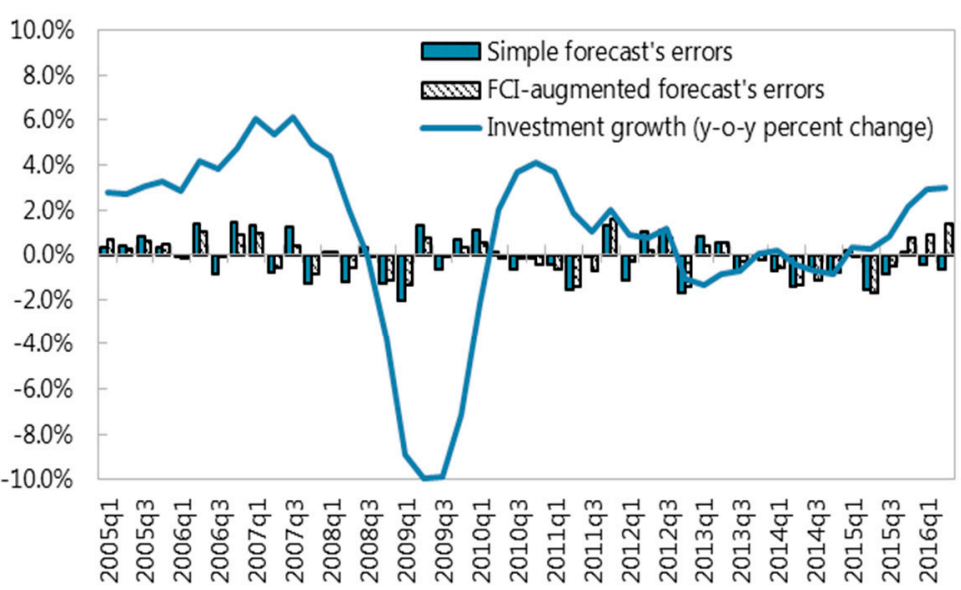

Consumption Forecast

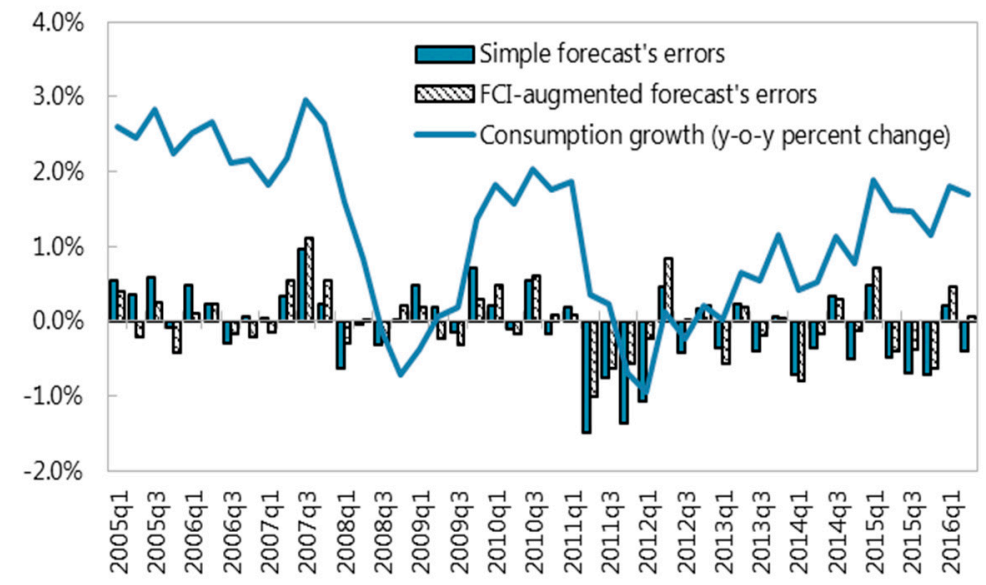

Exports Forecast

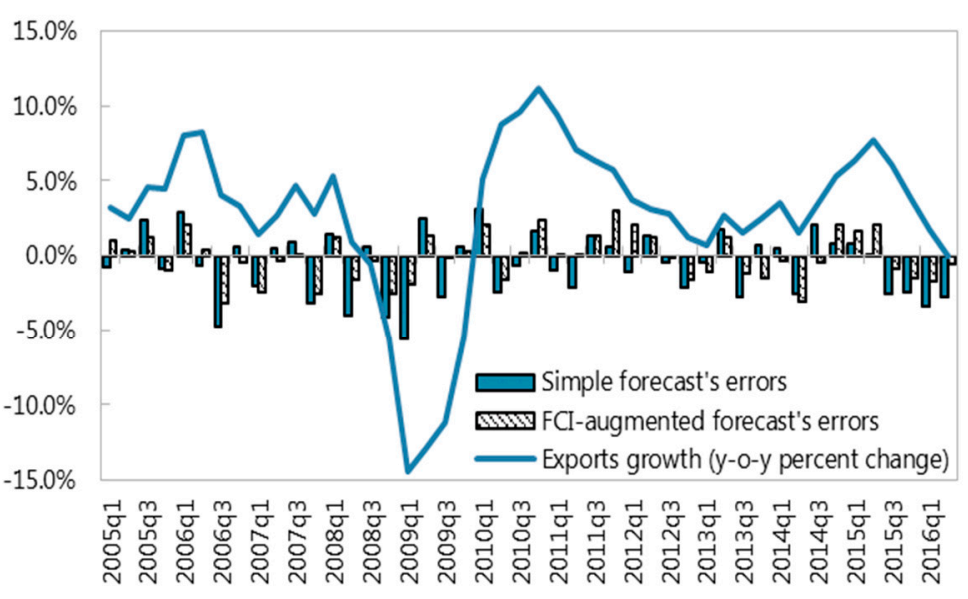

${ }^{1}$ We plot the growth rate of GDP and each of its components, as well as, for each of them, the forecast errors of one quarter horizon forecasts for the models without and with the FCI (on the estimation period). Blue bars correspond to the errors of the simple model without FCI, whereas stripped bars correspond to the errors of the FCIaugmented model. Focusing on the GDP graph, we can observe that the FCI-augmented forecast model performs better than the simple model without FCI, especially between 2006 and 2009. 


\section{Monitoring Activity During the Quarter}

Economic indicators providing quantitative information within the quarter are closely correlated with activity and can therefore be used to "now-cast" growth. The objective is to estimate a specific quarter's GDP growth before the publication of its first release, e.g. 45 days after the end of the quarter in the case of France. As financial data are available at high frequency and with short or no lags, introducing the most recent financial information in a standard within-quarter monitoring model should increase the set of information used for "now-cast" and therefore should improve the accuracy of intra-quarter estimates of current quarterly growth.

We construct monthly FCIs based on our findings obtained at a quarterly frequency. The GDP, consumption, exports and investment-linked FCIs use the same financial variables and the same weights as in the quarterly FCIs, but at a monthly frequency instead.

Quarterly GDP growth and its components are estimated from monthly indicators of the real economy and the monthly FCIs. For each of our targeted quarterly dependent variables, we estimate three different models, relying upon the data available on the first, second and third month of the quarter respectively $(\mathrm{m}=1,2,3)$ :

$$
g_{\text {quarterly }}^{y-o-y}=\alpha+\sum_{i=1}^{m} \beta * X_{m-i}^{\text {macro }}+\sum_{i=1}^{m} \theta * F C I_{m-i}
$$

Where $g$ corresponds to the year-on-year growth rate of the dependent variable (GDP, consumption, investment or Exports), $X$ corresponds to the macro indicators used in the forecast and FCI to the monthly FCI tailored to this target variable. For example, the second month model $(\mathrm{m}=2)$ will rely on data available in the previous month $(\mathrm{m}-1)$ and in the month before (m-2). The use of previous period's data is due to the availability of the monthly indicators, which are released with a one-month lag. The economic indicators used in the benchmark models are those that have been found to work reasonably well in predicting quarter-on-quarter growth in practice: industrial production and households' consumption expenditure of manufactured goods for GDP, industrial production of investment goods and NFCs' investment (quarterly variable) for investment, consumption expenditure for consumption and exports volume for the exports' equation. We estimate the three benchmark models with and without the relevant FCI. The nowcast model can be updated three times per quarter, using the data which becomes available after the end of each month. As done for the quarterly forecast models, we compare the RMSEs of the FCI-augmented models with the RMSEs of the benchmark models (Table 8).

\begin{tabular}{|l|llll|}
\hline \multicolumn{5}{|c|}{$\begin{array}{c}\text { Table 8. Nowcast Models: RMSEs Relative } \\
\text { to Benchmark Model without FCI }\end{array}$} \\
\hline & $\begin{array}{c}\text { 1st } \\
\text { month }\end{array}$ & $\begin{array}{c}\text { 2nd } \\
\text { month }\end{array}$ & $\begin{array}{c}\text { 3rd } \\
\text { month }\end{array}$ & average \\
\hline $\begin{array}{l}\text { GDP growth } \\
\text { FCI augmented model }\end{array}$ & 0.94 & 0.95 & 0.99 & 0.96 \\
\hline $\begin{array}{l}\text { Consumption growth } \\
\text { FCI augmented model }\end{array}$ & 0.89 & 0.88 & 0.90 & 0.89 \\
\hline $\begin{array}{l}\text { Investment growth } \\
\text { FCI augmented model }\end{array}$ & 0.81 & 0.86 & 0.97 & 0.88 \\
\hline $\begin{array}{l}\text { Exports growth } \\
\text { FCI augmented model }\end{array}$ & 0.88 & 0.91 & 0.93 & 0.91 \\
\hline
\end{tabular}


The FCI-augmented models do improve within-quarter now-cast performance in this in-sample exercise. A difference with the quarterly models is that we find the added-value to be higher for the components of GDP than for GDP, which may be due to the fact that the GDP benchmark model (without FCI) already performs very well. Moreover, financial conditions tend to improve the now-casts more at the beginning of the quarter (first and second month models) than at the end of the quarter (especially for investment and GDP).

Adding financial conditions increases nowcast performance much more in the first month model. Appendix D shows the estimates of the now-cast models for GDP and its components, with and without FCI, corresponding to the forecast models for each of the three months of the quarter. We find that:

- $\quad$ Explanatory power is higher for each of the models augmented with an FCI, compared to the benchmark model without FCI;

- In every model with an FCI, a tightening of financial conditions has a negative impact on the growth rate of the targeted real variable, but the magnitude of this effect decreases over the quarter (as well as its significance in the GDP and exports models). Hence, the second month FCI (used in the third month model) explains current growth dynamics less well than the first month FCI or the FCI of the last month of the previous quarter (respectively used in the second month and first month now-cast models).

- $\quad$ For investment, the explanatory power of the benchmark models of the second and third months are lower than respectively the ones of the augmented models of the first and second months. This suggests that adding financial data allows to now-cast investment at least as accurately, but earlier during the quarter.

\section{CONCLUSION}

We show that financial conditions can be a useful leading indicator for real economic activity in France. This evidence is consistent with what has been found for other countries. Our methodology developed to construct tailored FCIs makes it possible to augment standard macroeconomic forecast models and to significantly improve the accuracy of projections. This was consistently found at both the quarterly and monthly frequencies, for GDP and its components. Indeed, we show that FCI-augmented models could have significantly improved GDP forecasts before and during the global financial crisis. In nowcast models, the tailored FCI has a particularly strong impact on the accuracy of in-quarter forecasts within the first month.

Based on the results for GDP and its components, we derive a clearer picture of transmission channels in France, namely that certain financial conditions, especially stock market and credit spreads, are strong leading indicators via their effect primarily on enterprise investment, and to a lesser extent on exports. By contrast, household's consumption is contemporaneously impacted by changes in financial conditions, perhaps as a result of wealth effects, impact on expectations, or common shocks on consumer and market sentiment. 
Equity market returns turn out to be the strongest component of all tailored FCIs. This finding may be surprising because France's stock market plays a more limited role in financing the economy compared to countries such as the US or UK. It could reflect the role of equity prices as informative signals of near-term real activity, in particular with regard to investment, which is a key transmission channel in France. Private risk premiums, interest rates, and credit standards are also significant components, but their relative weights vary across GDP and its three components. Interestingly, credit volumes turn out to be lagging indicators of growth, suggesting that credit growth in France is demand-driven rather than supply-driven.

Next steps could consist of real-time performance assessment or scenario analysis.

Further analysis could look for the best performing model in a real-time exercise in an outof-sample framework. This has not been done yet because of the short time span on which data is available. Also, this type of FCI could be used for scenario analysis purposes, applying shocks to the financial variables entering the financial conditions index, and assessing their impact on real activity. 


\section{REFERENCES}

Allard-Prigent C., Audenis C., Berger K., Carnot N., Duchene S., Pesin F., 2002.

Présentation du modèle MESANGE, Modèle Économétrique de Simulation et d'Analyse Générale de l'Économie. Document de travail du Ministère de l'Économie, des Finances et de l'Industrie, No. 326640.

Altavilla, C., Darracq Paries, M., Nicoletti, G., 2015. Loan Supply, Credit Markets and the Euro Area Financial Crisis. European Central Bank Working Paper Series, No. 1861.

Angelopoulou, E., Balfoussia, H., Gibson, H., 2013. Building a Financial Conditions Index for the Euro Area and Selected Euro Area Countries: What Does it Tell us About the Crisis? European Central Bank Working Paper Series, No. 1541.

Arrondel, L., Savignac, F, and Tracol, K., 2014. Wealth and Consumption: French Households in the Crisis. International Journal of Central Banking, Vol. 10, No. 3.

Barhoumi, K., Benk, S., Cristadoro, R., Den Reijer A., Jakaitiene, A., Jelonek, P., Rua, A., Runstler, G., Ruth, K., Van Nieuwenhuyze, C., 2009. Short-term Forecasting of GDP using Large Monthly Datasets: A Pseudo Real-Time Forecast Evaluation Exercise. Journal of forecasting, Vol. 8, Issue 7, pp 595-611.

Bec, F., Mogliani, M., 2015. Nowcasting French GDP in Real-Time with Surveys and "Blocked" Regressions: Combining Forecasts or Pooling Information? International Journal of Forecasting, Vol. 31, Issue 4, pp 1021-1042.

Brave, S., Butters, R.A., 2012. Diagnosing the Financial System: Financial Conditions and Financial Stress. International Journal of Central Banking, Vol.8, No. 2.

Combes, S., Doz, C., Fournier, J.-M., 2013. Prévision de Court terme de la croissance du PIB français à l'aide de modèles à facteurs dynamiques: impact de la sélection des variables. Document de travail de la DG Trésor, No. 2013/02.

Chauvin, V.,Damette, O.,2010. Wealth Effects: the French Case. Banque de France Working Paper, No. 276.

D‘Antonio, P., 2008. A View of the U.S. Subprime Crisis. Citigroup Global Markets EMA Special Report, September 2008, pp. 26-28.

Darracq Paries, M., Maurin, L. and Moccero, D., 2014. Financial Conditions Index and Credit Supply Shocks for the Euro Area. European Central Bank Working Paper, No. 1644.

Duprey, T., Klaus, B., Peltonen, T., 2017. Dating Systemic Financial Stress Episodes in the EU Countries. Journal of Financial Stability, Vol. 32, pp 30-56.

English, W., Tsatsaronis, K., Zoli, E., 2005. Assessing the Predictive Power of Measures of Financial Conditions for Macroeconomic Variables. Bank of International Settlements Papers, No. 22. 
Gerdrup, K. R., Hammersland, R., Naug, B. E., 2006. Financial Variables and Developments in the Real Economy. Norges Bank Economic Bulletin, 3/2006, Vol 77, pp 133-146.

Gilbert, P. D., and Meijer, E., 2005. Time Series Factor Analysis with an Application to Measuring Money. University of Groningen Working Paper.

Goldman Sachs, 2015. Ongoing Support for Euro Area Recovery from Financial Conditions. European Economics Daily, Goldman Sachs Research, September 23.

Gauthier, C., Graham, C., Liu, Y., 2004. Financial Conditions Indexes for Canada. Bank of Canada Staff Working Paper, No. 2004-22.

Goodhart, C., Hofmann, B., 2001. Asset prices, Financial Conditions, and the Transmission of Monetary Policy. Working Paper Stanford University.

Guichard, S., Turner, D., 2008. Quantifying the Effect of Financial Conditions on US Activity. OECD Economics Department Working Papers, No. 635.

Hatzius, J., Hooper, P., Mishkin, F.S., Schoenholtz, K.L., Watson, M.W., 2010. Financial Conditions Indexes: A Fresh Look after the Financial Crisis. NBER Working Paper, No. 16150.

Hooper, P., Mayer T. and Slok T., 2007. Financial Conditions: Central Banks Still Ahead of Markets. Deutsche Bank Global Economic Perspectives, June 11.

International Monetary Fund, 2008. Financial Stress and Economic Downturns. World Economic Outlook, Oct. 2008, Appendix 4.1.

International Monetary Fund, 2016. France: Selected Issues. IMF Country Report No. 16/228, July 2016.

International Monetary Fund, 2017. "Are Countries Losing Control of Domestic Financial Conditions?”, Global Financial Stability Report, Chapter 3, Spring 2017.

Kliesen, K.L., Owyang, M.T., Vermann, E.K., 2012. Disentangling Diverse Measures: A Survey of Financial Stress Indexes. Federal Reserve of St. Louis Review, Sept/Oct 2012, 94(5), pp 369-97.

Kliesen, K.L. and Smith, D.C., 2010. Measuring Financial Market Stress. Federal Reserve Bank of St. Louis National Economic Synopses, No. 2.

Krainz, D.M., 2011. An Evaluation of the Forecasting Performance of Three Econometric Models for the Eurozone and the USA. WIFO Working Paper, No. 399.

Lalande, E., Rioust de Largentaye, T., 2015. La Prévision de Croissance de Court-Terme à la DG Trésor. Documents de travail de la DG Trésor, No. 2015/04. 
Levieuge, G., 2015. Explaining and Forecasting Bank Loans. Good Times and Crisis. Banque de France Working Paper, No. 566.

Matheson, T. D., 2012. Financial Conditions Indexes for the United States and Euro Area. Economic Letters, Vol. 115, Issue 3, pp 441-446.

Morgan Stanley, 2015. Financial Conditions in the Euro Area. Morgan Stanley European Economics, June 8.

Pouvelle, C., 2012. Bank Credit, Asset Prices and Financial Stability: Evidence from French Banks. International Monetary Fund Working Paper, No. 12/103.

Rosenberg, M. R., 2008. Financial Conditions Watch, Bloomberg, September 2008.

Sédillot, F., Pain, N., 2005. Modèles d'Indicateurs de la Croissance du PIB Réel dans les Principales Economies de l'OCDE. Revue économique de l'OCDE, Vol. 1, No. 40, pp 185-246.

Swiston, A., 2008. A U.S. Financial Conditions Index: Putting Credit Where Credit is Due. International Monetary Fund Working Paper, No. 08/161.

Wacker, K.M., Lodge, D., Nicoletti, G., 2014. Measuring Financial Conditions in Major Non-Euro Area Economies. European Central Bank Working Paper Series, No. 1743. 


\section{APPENDIX}

\section{A. Data Description}

\begin{tabular}{|c|c|c|}
\hline \multicolumn{3}{|c|}{ Table A1. Quarterly Variables } \\
\hline Financial variables (standardized) & Transformation & Source \\
\hline 10-year Treasury note interest rate & y-o-y difference & $\begin{array}{l}\text { Haver Analytics } \\
\text { (Bank of France) }\end{array}$ \\
\hline $\begin{array}{l}\text { Spread on loans to NFCs over } 2 \text { years (to } 10 \mathrm{Y} \text { T-note } \\
\text { interest rate) }\end{array}$ & y-o-y difference & $\begin{array}{l}\text { Haver Analytics } \\
\text { (Bank of France) }\end{array}$ \\
\hline $\begin{array}{l}\text { Spread on new housing loans } \\
\text { (to } 10 \mathrm{Y} \text { T-note interest rate) }\end{array}$ & y-o-y difference & Haver Analytics \\
\hline $\begin{array}{l}\text { Change in credit standards to enterprises (over the past } \\
\text { quarter) }\end{array}$ & None & $\begin{array}{l}\text { Haver Analytics } \\
\text { (Bank Lending survey) }\end{array}$ \\
\hline $\begin{array}{l}\text { Change in credit standards for mortgages (over the past } \\
\text { quarter) }\end{array}$ & None & $\begin{array}{l}\text { Haver Analytics } \\
\text { (Bank Lending survey) }\end{array}$ \\
\hline CAC40 total return index & y-o-y growth & $\begin{array}{l}\text { Haver Analytics } \\
\text { (NYSE Euronext) }\end{array}$ \\
\hline Macroeconomic variables & Transformation & Source \\
\hline Real GDP & y-o-y growth & Haver Analytics \\
\hline $\begin{array}{l}\text { Real private consumption (household and nonprofit } \\
\text { institutions) }\end{array}$ & y-o-y growth & Haver Analytics \\
\hline Real gross fixed capital formation & y-o-y growth & Haver Analytics \\
\hline Real exports of goods and services & y-o-y growth & Haver Analytics \\
\hline Harmonized consumer price index & y-o-y growth & Haver Analytics \\
\hline Unemployed labor force & y-o-y growth & $\begin{array}{l}\text { Haver Analytics } \\
\text { (INSEE Labor force survey) }\end{array}$ \\
\hline World average crude oil price & y-o-y growth & Haver Analytics \\
\hline Real world GDP & y-o-y growth & IMF WEO \\
\hline Real effective exchange rate & y-o-y growth & IMF Information Notice System \\
\hline $\begin{array}{l}\text { Real gross fixed capital formation for NFCs (used in } \\
\text { nowcast models for Investment) }\end{array}$ & y-o-y growth & Haver Analytics \\
\hline
\end{tabular}

\begin{tabular}{|l|l|l|}
\hline \multicolumn{2}{|c|}{ Table A2. Monthly Variables } \\
\hline Financial variables (standardized) & Transformation & Source \\
\hline 10-year Treasury note interest rate & y-o-y difference & $\begin{array}{l}\text { Haver Analytics } \\
\text { (Bank of France) }\end{array}$ \\
\hline $\begin{array}{l}\text { Spread on MFI new lending to domestic NFCs (to 10Y T-note } \\
\text { interest rate) }\end{array}$ & y-o-y difference & Haver Analytics \\
\hline $\begin{array}{l}\text { Spread on new housing loans to domestic households } \\
\text { to 10Y T-note interest rate) }\end{array}$ & y-o-y difference & Haver Analytics \\
\hline $\begin{array}{l}\text { CAC40 total return index } \\
\text { Macroeconomic variables }\end{array}$ & y-o-y growth & $\begin{array}{l}\text { Haver Analytics } \\
\text { (NYSE Euronext) }\end{array}$ \\
\hline Manufacturing industrial production & Transformation & Source \\
\hline Industrial production: investment goods & y-o-y growth & Haver Analytics \\
\hline Household consumption expenditure: manufactured goods & y-o-y growth & Haver Analytics \\
\hline Export volume: goods & y-o-y growth & Haver Analytics \\
\hline
\end{tabular}




\section{B. Construction of the FCIs Linked to Components of GDP}

The following VAR equation is estimated:

$$
X_{t}=\alpha+\sum_{i=1}^{p} \theta_{i} X_{t-i}+\varepsilon_{t}
$$

Where $\mathrm{X}$ is a vector of jointly determined stationary variables: real growth in the economic variable (GDP, C, I or E), harmonized CPI inflation, and all the financial variables selected to be included in the FCI. These financial variables are previously transformed to avoid non-stationarity, and standardized (demeaned and divided by their standard deviation). The lag length of the VAR is determined by information criterion lag-order selection statistics ${ }^{1}$. Stability tests are also conducted. The weight of each of the financial variables in the FCI is computed as being equal to the average cumulative impact of a 1-unit shock of this variable on the real economy variable's growth over the following 8 quarters, based on the cumulative orthogonalized impulse response functions derived from this VAR. This time period is chosen: i) to capture the complete effect of the financial variable which may be transmitted with some lags; ii) because current and lagged FCI values will then be used to improve forecasts of current to three quarters ahead's activity. FCIs are normalized such that a 1-unit increase in the FCI corresponds to the effect on the economic variable's growth of a one-unit change in the long-term risk free rate included in the $\mathrm{VAR}^{2}$.

\begin{tabular}{|c|c|c|c|c|}
\hline \multicolumn{5}{|c|}{ Table A3. Financial Variables Integrated in the FCIs } \\
\hline Category & GDP & Investment & Consumption & Exports \\
\hline Interest rate & $\begin{array}{c}\text { Long-term risk free } \\
\text { rate }\end{array}$ & $\begin{array}{c}\text { Long-term risk free } \\
\text { rate }\end{array}$ & $\begin{array}{c}\text { Long-term risk free } \\
\text { rate }\end{array}$ & \\
\hline $\begin{array}{c}\text { Spread or "risk } \\
\text { premium" }\end{array}$ & $\begin{array}{c}\text { NFC spread (to long- } \\
\text { term risk free rate) }\end{array}$ & $\begin{array}{c}\text { NFC spread (to long- } \\
\text { term risk free rate) }\end{array}$ & $\begin{array}{c}\text { Mortgage spread (to } \\
\text { long-term risk free } \\
\text { rate) }\end{array}$ & $\begin{array}{c}\text { NFC spread (to } \\
\text { long-term risk } \\
\text { free rate) }\end{array}$ \\
\hline Equity market & CAC 40 returns & CAC 40 returns & CAC 40 returns & CAC 40 returns \\
\hline Credit standards & $\begin{array}{c}\text { Enterprises and } \\
\text { mortgage bank } \\
\text { lending standards } \\
\text { (BLS) }\end{array}$ & Enterprise BLS & Mortgage BLS & Enterprise BLS \\
\hline $\begin{array}{l}{ }^{1} \text { The long-term interest rate was not integrated into this FCI because it had a very low impact on exports growth. } \\
\text { Note: See Appendix B for the details of the financial variables integrated in each specific FCI }\end{array}$ \\
\hline
\end{tabular}

\footnotetext{
${ }^{1}$ If different information criteria point to different possible lag lengths, we choose the lag length that minimizes the autocorrelation in the residuals.

${ }^{2}$ Except for the Exports FCI, for which the FCI is standardized based on the risk premium's weight.
} 


\section{Granger Causality Tests}

Granger causality tests are run after fitting the quarterly VAR forecasts. These tests are performed with vargranger, on Stata. The Granger-causality tests indicate if past values of the target-specific FCIs are useful to predict the targeted variable, given its past values. Failure to reject the null hypothesis is equivalent to failing to reject the hypothesis that they do not granger-cause the targeted variable.

\begin{tabular}{|l|lll|}
\hline \multicolumn{4}{|c|}{ Table A4. Causality from the Specific FCIs to the Targeted Variables } \\
\hline GDP-linked FCI & chi2 & $\mathrm{df}$ & $\mathrm{p}$-value \\
\hline Current GDP growth & 21.3 & 4.0 & 0.000 \\
1 quarter ahead GDP growth & 37.6 & 2.0 & 0.000 \\
2 quarters ahead GDP growth & 25.1 & 2.0 & 0.000 \\
3 quarters ahead GDP growth & 14.3 & 2.0 & 0.001 \\
\hline Consumption-linked FCI & chi2 & $\mathrm{df}$ & p-value \\
\hline Current consumption growth & 0.3 & 2.0 & 0.874 \\
1 quarter ahead consumption growth & 3.4 & 2.0 & 0.182 \\
2 quarters ahead consumption growth & 0.3 & 2.0 & 0.844 \\
3 quarters ahead consumption growth & 3.2 & 2.0 & 0.200 \\
\hline Investment-linked FCI & chi2 & $\mathrm{df}$ & $\mathrm{p}$-value \\
\hline Current Investment growth & 9.0 & 1.0 & 0.003 \\
1 quarter ahead investment growth & 4.5 & 2.0 & 0.108 \\
2 quarters ahead investment growth & 5.6 & 2.0 & 0.062 \\
3 quarters ahead investment growth & 10.1 & 2.0 & 0.006 \\
\hline Exports-linked FCI & chi2 & $\mathrm{df}$ & $\mathrm{p}$-value \\
\hline Current exports growth & 3.4 & 2.0 & 0.182 \\
1 quarter ahead exports growth & 6.1 & 2.0 & 0.048 \\
2 quarters ahead exports growth & 2.0 & 2.0 & 0.373 \\
3 quarters ahead exports growth & 3.4 & 2.0 & 0.186 \\
\hline
\end{tabular}

\begin{tabular}{|l|ccc|}
\hline \multicolumn{4}{|c|}{ Table A5. Causality from the GDP-linked FCI to Credit Flows } \\
\hline GDP-linked FCI ${ }^{1}$ & chi2 & df & p-value \\
\hline Current Credit flows & 4.398 & 2 & 0.111 \\
1 quarter ahead Credit flows & 4.012 & 2 & 0.135 \\
2 quarters ahead Credit flows & 7.245 & 2 & 0.027 \\
3 quarters ahead Credit flows & 8.820 & 2 & 0.012 \\
${ }^{1}$ Granger causality tests are run after VAR estimates that integrate the GDP-linked FCI, inflation and credit growth. They \\
indicate if past values of the GDP-linked FCIs are useful to predict the credit flows, given its past values. Failure to reject \\
the null hypothesis is equivalent to failing to reject the hypothesis that the GDP-linked FCI does not granger-cause the \\
credit flows.
\end{tabular}




\section{Nowcast Models}

\begin{tabular}{|c|c|c|c|c|c|c|}
\hline \multicolumn{7}{|c|}{ Table A6. GDP Nowcast Model } \\
\hline & \multicolumn{2}{|l|}{ First month } & \multicolumn{2}{|c|}{ Second month } & \multicolumn{2}{|c|}{ Third month } \\
\hline$I P_{m 1}$ & $0.225^{* * *}$ & $0.226^{* * *}$ & $0.115^{* * *}$ & $0.123 * * *$ & $0.150 * * *$ & $0.159 * * *$ \\
\hline Cons $_{m 1}^{H H}$ & $0.273 * * *$ & $0.212 * * *$ & & & & \\
\hline$F C I_{m 1}$ & & $-0.0443 *$ & & & & \\
\hline$I P_{m 2}$ & & & $0.120 * * *$ & $0.109 * *$ & & \\
\hline Cons $_{m 2}^{H H}$ & & & $0.291 * * *$ & $0.260 * * *$ & & \\
\hline$F C I_{m 2}$ & & & & $-0.0339 * *$ & & \\
\hline$I P_{m 3}$ & & & & & $0.0910 * * *$ & $0.0842 * * *$ \\
\hline $\operatorname{Cons}_{m 3}^{H H}$ & & & & & $0.230 * * *$ & $0.226 * * *$ \\
\hline$F C I_{m 3}$ & & & & & & -0.00987 \\
\hline Constant & $0.964 * * *$ & $0.960 * * *$ & $0.973 * * *$ & $0.958 * * *$ & $1.060 * * *$ & $0.991 * * *$ \\
\hline Observations & 61 & 49 & 61 & 50 & 61 & 50 \\
\hline Adjusted R2 & 0.80 & 0.83 & 0.86 & 0.88 & 0.87 & 0.89 \\
\hline \multicolumn{7}{|c|}{$* * * \mathrm{p}<0.01, * * \mathrm{p}<0.05, * \mathrm{p}<0.1$} \\
\hline $\begin{array}{l}\text { IP refers to ma } \\
\text { manufactured } \\
\text { the } \mathrm{i}^{\text {th }} \text { month of } \\
\text { data of the last } \\
\text { the current qua } \\
\text { two first month }\end{array}$ & $\begin{array}{l}\text { turing Indust } \\
X_{m i} \text { refers to } \\
\text { er. Hence, he } \\
\text { h of the previ } \\
\text { nd of the last } \\
\text { he current que }\end{array}$ & $\begin{array}{l}\text { ll productio } \\
\text { e observati } \\
\text { data is ava } \\
\text { s quarter. T } \\
\text { onth of pre } \\
\text { er and of th }\end{array}$ & $\begin{array}{l}\text { and Cons }{ }^{H} \\
\text { of the vari } \\
\text { ole with a } \\
\text { second mo } \\
\text { us quarter } \\
\text { ast month }\end{array}$ & $\begin{array}{l}\text { o Househol } \\
\text { X which is } \\
\text { month lag, } \\
\text { model relie } \\
\text { e third mon } \\
\text { ee previous }\end{array}$ & $\begin{array}{l}\text { consumption } \\
\text { first month } \\
\text { on data of th } \\
\text { model relie } \\
\text { arter. }\end{array}$ & $\begin{array}{l}\text { tpenditure of } \\
\text { ter the end of } \\
\text { odel relies on } \\
\text { irst month of } \\
n \text { data of the }\end{array}$ \\
\hline
\end{tabular}




\begin{tabular}{|c|c|c|c|c|c|c|}
\hline \multicolumn{7}{|c|}{ Table A7. Consumption Nowcast Model } \\
\hline & \multicolumn{2}{|c|}{ First month } & \multicolumn{2}{|c|}{ Second month } & \multicolumn{2}{|c|}{ Third month } \\
\hline Cons $_{m 1}^{H H}$ & $0.413 * * *$ & $0.309 * * *$ & $0.165 * * *$ & 0.0739 & & \\
\hline$F C I_{m 1}$ & & $-0.123 * * *$ & & & & \\
\hline Cons $_{m 2}^{H H}$ & & & $0.424 * * *$ & $0.424 * * *$ & $0.252 * * *$ & $0.188 * * *$ \\
\hline$F C I_{m 2}$ & & & & $-0.0911 * * *$ & & \\
\hline $\operatorname{Cons}_{m 3}^{H H}$ & & & & & $0.327 * * *$ & $0.329 * * *$ \\
\hline$F C I_{m 3}$ & & & & & & $-0.0509 * * *$ \\
\hline Constant & $0.852 * * *$ & $0.846^{* * *}$ & $0.662 * * *$ & $0.681 * * *$ & $0.707 * * *$ & $0.663 * * *$ \\
\hline Observations & 61 & 49 & 61 & 50 & 62 & 50 \\
\hline Adjusted R2 & 0.49 & 0.57 & 0.71 & 0.78 & 0.81 & 0.88 \\
\hline \multicolumn{7}{|c|}{$\begin{array}{l}* * * \mathrm{p}<0.01, * * \mathrm{p}<0.05, * \mathrm{p}<0.1 \\
\text { Cons }{ }^{H H} \text { refers to Household consumption expenditure of manufactured goods. } X_{m i} \text { refers to the observation } \\
\text { of the variable } \mathrm{X} \text { which is released right after the end of the } \mathrm{i}^{\text {th }} \text { month of quarter. Hence, here, data is available } \\
\text { with a one-month lag, the first month model relies on data of the last month of the previous quarter. The } \\
\text { second month model relies on data of the first month of the current quarter and of the last month of previous } \\
\text { quarter. The third month model relies on data of the two first months of the current quarter. }\end{array}$} \\
\hline
\end{tabular}




\begin{tabular}{|c|c|c|c|c|c|c|}
\hline \multicolumn{7}{|c|}{ Table A8. Investment Nowcast Model } \\
\hline & \multicolumn{2}{|c|}{ First month } & \multicolumn{2}{|c|}{ Second month } & \multicolumn{2}{|c|}{ Third month } \\
\hline $\operatorname{Inv} v_{q}^{N F C}$ & $0.415^{* * *}$ & $0.481 * * *$ & $0.329 * * *$ & $0.446 * * *$ & $0.308 * * *$ & $0.417 * * *$ \\
\hline$I P_{m 1}^{N F C}$ & $0.217 * * *$ & $0.153 * * *$ & & & & \\
\hline$F C I_{m 1}$ & & $-0.303 * * *$ & & & & \\
\hline$I P_{m 2}^{N F C}$ & & & $0.305^{* * *}$ & $0.213 * * *$ & $0.166^{* * *}$ & $0.126^{* *}$ \\
\hline$F C I_{m 2}$ & & & & $-0.265^{* * *}$ & & \\
\hline$I P_{m 3}^{N F C}$ & & & & & $0.186^{* * *}$ & $0.150 * *$ \\
\hline$F C I_{m 3}$ & & & & & & $-0.164 * * *$ \\
\hline Constant & & & $0.427 * *$ & & $0.464 * *$ & \\
\hline Observations & 61 & 49 & 61 & 50 & 61 & 50 \\
\hline Adjusted R2 & 0.73 & 0.85 & 0.80 & 0.89 & 0.84 & 0.90 \\
\hline \multicolumn{7}{|c|}{$\begin{array}{l}\text { *** } \mathrm{p}<0.01,{ }^{* *} \mathrm{p}<0.05, * \mathrm{p}<0.1 \\
\text { Inv } v_{q}^{N F C} \text { refers to previous quarter's nonfinancial corporations' investment, } I P^{N F C} \text { to industrial production in } \\
\text { investment goods. } X_{m i} \text { refers to the observation of the variable } \mathrm{X} \text { which is released right after the end of the } \\
\mathrm{i}^{\text {th }} \text { month of quarter. Hence, here, as data is available with a one-month lag and relies on previous quarter's } \\
\text { NFCs investment, the first month model relies on data of the previous quarter. The second month model } \\
\text { relies on data of the first month of the current quarter and of the previous quarter. The third month model } \\
\text { relies on data of the two first months of the current quarter and of the previous quarter. }\end{array}$} \\
\hline
\end{tabular}




\begin{tabular}{|c|c|c|c|c|c|c|}
\hline \multicolumn{7}{|c|}{ Table A9. Exports Nowcast Model } \\
\hline & \multicolumn{2}{|c|}{ First month } & \multicolumn{2}{|c|}{ Second month } & \multicolumn{2}{|c|}{ Third month } \\
\hline $\operatorname{Exp}_{m 1}^{v o l}$ & $0.377 * * *$ & $0.350 * * *$ & $0.282 * * *$ & $0.265^{* * *}$ & $0.187 * *$ & $0.204 * *$ \\
\hline$F C I_{m 1}$ & & $-0.760 * * *$ & & & & \\
\hline $\operatorname{Exp} p_{m 2}^{v o l}$ & & & $0.210 * * *$ & $0.193 * * *$ & $0.168 * *$ & $0.167 * *$ \\
\hline$F C I_{m 2}$ & & & & $-0.647 * *$ & & \\
\hline $\operatorname{Exp}_{m 3}^{\text {vol }}$ & & & & & $0.227 * *$ & $0.174 * *$ \\
\hline$F C I_{m 3}$ & & & & & & $-0.551 * *$ \\
\hline Constant & $2.244 * * *$ & $1.853 * * *$ & $2.070 * * *$ & $1.828 * * *$ & $1.924 * * *$ & $1.811 * * *$ \\
\hline Observations & 61 & 49 & 61 & 50 & 61 & 50 \\
\hline Adjusted R2 & 0.38 & 0.52 & 0.45 & 0.54 & 0.53 & 0.58 \\
\hline \multicolumn{7}{|c|}{$\begin{array}{l}* * * \mathrm{p}<0.01,{ }^{* *} \mathrm{p}<0.05,{ }^{*} \mathrm{p}<0.1 \\
\text { Exp vol refers to exports volume of goods. } X_{m i} \text { refers to the observation of the variable } \mathrm{X} \text { which is released } \\
\text { right after the end of the } \mathrm{i}^{\text {th }} \text { month of quarter. Hence, here, as exports volume data is available with a two- } \\
\text { month lag and FCI with a one-month lag, the first month model relies on data from the two last months of } \\
\text { the previous quarter. The second month model relies on the same, augmented by FCI data from the first } \\
\text { month of the current quarter. The third month model relies on the same, augmented by FCI data from the } \\
\text { second month of the quarter. }\end{array}$} \\
\hline
\end{tabular}

